\title{
Adipose Tissue Biology: An Update Review
}

\author{
Anna Meiliana ${ }^{1,2 *}$ and Andi Wijaya ${ }^{1,2 *}$
}

\section{Abstract}

\section{$\mathrm{B}$}

ACKGROUND: Obesity is a major health problem in most countries in the world today. It increases the risk of diabetes, heart disease, fatty liver and some forms of cancer. Adipose tissue biology is currently one of the "hot" areas of biomedical science, as fundamental for the development of novel therapeutics for obesity and its related disorders.

CONTENT: Adipose tissue consists predominantly of adipocytes, adipose - derived stromal cells (ASCs), vascular endothelial cells, pericytes, fibroblasts, macrophages, and extracellular matrix. Adipose tissue metabolism is extremely dynamic, and the supply of and removal of substrates in the blood is acutely regulated according to the nutritional state. Adipose tissue possesses the ability to a very large extent to modulate its own metabolic activities including differentiation of new adipocytes and production of blood vessels as necessary to accommodate increasing fat stores. At the same time, adipocytes signal to other tissues to regulate their energy metabolism in accordance with the body's nutritional state. Ultimately adipocyte fat stores have to match the body's overall surplus or deficit of energy. Obesity causes adipose tissue dysfunction and results in obesity - related disorders.

SUMMARY: It is now clear that adipose tissue is a complex and highly active metabolic and endocrine organ. Understanding the molecular mechanisms underlying obesity and its associated disease cluster is also of great significance as the need for new and more effective therapeutic strategies is more urgent than ever.
KEYWORDS: Obesity, Adipocyte, Adipose Tissue, Adipogenesis, Angiogenesis, Lipid Droplet, Lipolysis, Plasticity, Dysfunction.

\section{Introduction}

Obesity is increasing in an epidemic manner in most countries and constitutes a public health problem by enhancing the risk for cardiovascular disease and metabolic disorders such as type 2 diabetes $(1,2)$. Owing to the increase in obesity, life expectancy may start to decrease in developed countries for the first time in recent history (3). The factors determining fat mass in adult humans are not fully understood, but increased lipid storage in already developed fat cells (adipocytes) is thought to be most important $(4,5)$.

Adipose tissue has now moved centre stage in obesity research, there having been a revolution in our understanding of the biological role of the tissue over the past decade. Indeed, adipose tissue biology is currently one of the 'hot' areas of biomedical science - principally because it is now recognized as a major endocrine and signalling organ (6).

White adipose tissue is part of what Cinti has termed 'the adipose organ', which consists of two functionally distinct tissues - brown and white adipose tissue. Brown adipose tissue is specialized for heat production by nonshivering thermogenesis, and in this tissue the stored lipid droplets serve primarily as a fuel for the production of heat. In white adipose tissue, on the other hand, the stored triacylglycerols provide a long-term fuel reserve for the animal (6). 
In addition to fuel storage, white adipose tissue can act as a thermal insulator and protect other organs from mechanical damage. Two further features of the tissue should be highlighted. First, unlike most other organs, white fat is distributed in multiple depots in the body, both subcutaneously and internally, and clusters of adipocytes may also be located adjacent to, or embedded in, other organs such as the lymph nodes and skeletal muscle. A second important feature is that adipose tissue is not made up simply of mature adipocytes, which store the lipid, but contains a variety of other cells (e.g. fibroblasts, endothelial cells, macrophages) which constitute around $50 \%$ of the total cellular content (6).

Adipocyte number is a major determinant for the fat mass in adults. However, the number of fat cells stays constant in adulthood in lean and obese individuals, even after marked weight loss, indicating that the number of adipocytes is set during childhood and adolescence. Approximately $10 \%$ of fat cells are renewed annually at all adult ages and levels of body mass index. Neither adipocyte death nor generation rate is altered in early onset obesity, suggesting a tight regulation of fat cell number in this condition during adulthood. The high turnover of adipocytes establishes a new therapeutic target for pharmacological intervention in obesity (7).

The fat mass can expand by increasing the average fat cell volume and/or the number of adipocytes. Increased fat storage in fully differentiated adipocytes, resulting in enlarged fat cells, is well documented and is thought to be the most important mechanism whereby fat depots increase in adults $(4,5)$.

The generation of adipocytes is a major factor behind the growth of adipose tissue during childhood, but it is unknown whether the number of adipocytes changes during adulthood (8).

The difference in adipocyte number between lean and obese individuals is established during childhood $(7,8)$ and the total number of adipocytes for each weight category stays constant during adulthood. The small variation in adipocyte number for each BMI category demonstrates that this is a stable cell population during adulthood. This may indicate that the number of adipocytes is set by early adulthood with no subsequent cell turnover. Alternatively, the generation of adipocytes may be balanced by adipocyte death, with the total number being tightly regulated and constant (7).

Adipocytes can be generated from adult human mesenchymal stem cells and pre-adipocytes in vitro (9) and may undergo apoptosis or necrosis $(10-12)$, but it is unclear whether adipocytes are generated in vivo (9).
Although the study by Spalding KL, et al show that the adipocyte number is static in adults, they also demonstrate that there is remarkable turnover within this population, indicating that adipocyte number is tightly controlled and not influenced by the energy balance. Thus, a tight regulation of adipocyte number, together with mechanisms maintaining their energy balance, may contribute to why obese individuals have difficulties maintaining weight loss (7).

Adipose tissue could play a crucial part in buffering the flux of fatty acids in the circulation in the postprandial period, analogous to the roles of the liver and skeletal muscle in buffering postprandial glucose fluxes. Adipose tissue provides its buffering action by suppressing the release of non-esterified fatty acids into the circulation and by increasing triacylglycerol clearance (13).

Adipose tissue buffering of lipid fluxes is impaired in obesity through defects in the ability of adipose tissue to respond rapidly to the dynamic situation that occurs after meals. It is also impaired in lipodystrophy because there is not sufficient adipose tissue to provide the necessary buffering capacity (13).

Much of Frayn's thesis would fit with the idea that, as adipocytes enlarge with fat storage, their efficiency as 'metabolic buffers' decreases. In this context, it is interesting that the thiazolodinedione insulin sensitizers act, via the nuclear receptor PPAR $\gamma$, to stimulate adipocyte differentiation and to increase the number of small adipocytes $(15,16)$. It could well be that the new, smaller adipocytes thus formed act as powerful 'buffers', avidly absorbing fatty acids in the postprandial period. Indeed, it has been proposed that an inability to differentiate new adipocytes as required for storage of excess energy underlies the development of Type II diabetes (17).

Adipose tissue metabolism is extremely dynamic, and the supply of and removal of substrates in the blood is acutely regulated according to the nutritional state. Adipose tissue possesses the ability to a very large extent to modulate its own metabolic activities, including differentiation of new adipocytes and production of blood vessels as necessary to accommodate increasing fat stores. At the same time, adipocytes signal to other tissues to regulate their energy metabolism in accordance with the body's nutritional state. Ultimately adipocyte fat stores have to match the body's overall surplus or deficit of energy (14).

Adipose tissue is now recognised as a highly active metabolic and endocrine organ. Great strides have been made in uncovering the multiple functions of the adipocyte in cellular and molecular detail (14). 


\section{Obesity}

The development of obesity is dependent on the coordinated interplay of adipocyte hypertrophy (increased fat cell size), adipocyte hyperplasia (increased fat cell number), and angiogenesis. Evidence suggests that adipocyte hyperplasia, or adipogenesis, occurs throughout life, both in response to normal cell turnover as well as in response to the need for additional fat mass stores that arises when caloric intake exceeds nutritional requirements (18).

Recent reports have suggested that disruptions in sleep patterns, often linked to our '24-h' lifestyle, are associated with increased body fat and altered metabolism, although the cause-effect relationship for these associations has yet to be elucidated. Abnormal sleep/wake patterns likely alter intracellular circadian clocks, which are molecular mechanisms that enable the cell/tissue/organism to anticipate diurnal variations in its environment. The environment may include circulating levels of nutrients (e.g. glucose, fatty acids and triglycerides) and various hormones (e.g. insulin, glucocorticoids). As such, alterations in this molecular mechanism, in particular within the adipocyte, likely induce metabolic changes that may potentiate disrupted metabolism, adipose accumulation and/or obesity. Although diurnal variations in adipokines and adipose tissue metabolism have been observed, little is known regarding the molecular mechanisms that influence these events (19). Circadian clocks are defined as a set of proteins that generate self-sustained transcriptional positive and negative feedback loops with a free-running period of $24 \mathrm{~h}(20)$.

There are three major components to the circadian clock (i) input signals (zeitgebers or timekeepers) which reset the circadian clock; (ii) the circadian clock mechanism itself and (iii) the output from the clock (which manifests at the level of altered gene and protein expression, metabolism and/or function, depending upon the cell/organ) (19).

The role of the peripheral circadian clock mechanism within the adipocyte represents an exciting new field of study in pursuit of the causes of increasing obesity prevalence. Elucidation of the link between the adipocytespecific circadian clock and obesity may have profound implications on the timing of obesity therapies (19).

One of the most important recent developments in obesity research is the emergence of the concept that obesity is characterized by chronic mild inflammation paralleling the situation with other diseases. The basis for this view is that the circulating level of several cytokines and acute phase proteins associated with inflammation is increased in the obese. As adipocytes secrete a number of cytokines and acute phase proteins, it is considered that the expanded adipose tissue mass contributes, either directly or indirectly, to the increased production and circulating levels of inflammation-related factors in obesity. In other words, the state of inflammation in adipose tissue in obesity leads to an increased production and release of inflammation-related factors (6).

Previous studies have demonstrated that the enlargement of adipocytes is associated with substantial changes in metabolic functions, e.g. in lipid metabolism $(21,22)$. It has been hypothesized that such alterations may contribute to the health risks of obesity. Recently, adipocyte size in the sc abdominal depot was identified to be a significant predictor for the future development of diabetes mellitus type 2 (23). Adipocytes are known to release a variety of factors, including cytokines, chemokines, and many other biologically active molecules, commonly called adipokines. These secreted products may be involved in the development of a chronic low-grade inflammatory state, which may represent the "common soil" for the pathogenesis of the metabolic and cardiovascular complications of obesity $(24,25)$.

Obesity is linked to a variety of metabolic disorders, such as insulin resistance and atherosclerosis. Dysregulated production of fat - derived secretory factors, adipocytokines, is partly responsible for obesity - linked metabolic disorders (26).

\section{Adipogenesis}

Adipose tissue is the only organ in the body that can markedly alter its total mass from $10-20$ kilograms in the normal state to several hundreds kilograms in subjects with monogenic disorders of obesity. After obesity is established, the adipose mass can be reduced to normal a few years after bariatric surgery or following a successful change in caloric intake/physical activity. How is this plasticity of adipose tissue possible? The adipose tissue mass can expand in two different ways. Pre - existing fat cells can accumulate more lipids so the volume of the cell increases. Alternatively, new fat cells are made from progenitor cells in the stroma of adipose tissue such as mesenchymal cells or already commited precursor cells (preadipocytes) (27).

It was demonstrated that about $10 \%$ of the total fat cell pool is renewed every year due to constant generation of new fat cells. However, this production is counterbalanced by an equal rate of fat cell death keeping the total amount 
of fat cells constant overtime in adulthood, even marked body weight reduction. This turnover process was found to be much accelerated among obese subjects who have a two times higher rate of generation of new fat cells in spite of the same relative death rate of old fat cells as lean subjects. Thus, there is a marked ongoing adipogenesis in adult humans which may be an important factor for weight gain and difficulties in retaining weight loss after slimming (27).

Both adipocyte hypertrophy and hyperplasia occur during normal growth phases and during the development of obesity $(8,28,29)$. Hypertrophy often precedes hyperplasia in a cyclic manner. Hyperplasia, herein referred to as "adipogenesis," represents the complex process by which new fat cells are developed from adipocyte precursor fat cells called preadipocytes. Adipogenesis involves two major events - the recruitment and proliferation of preadipocytes followed by their subsequent differentiation into mature fat cells (31-33). "Proliferation" refers to the process by which preadipocytes replicate so as to increase fat cell number, whereas "differentiation" refers to the process by which undifferentiated, proliferating fibroblastlike preadipocytes become permanently cell cycle arrested, spherical, lipid-filled and functionally mature fat cells (31). Differentiation is accompanied by dramatic alterations in cell shape as well as by molecular changes that lead to dramatic increases in the ability of the cell for lipid synthesis and increases in hormonal responsiveness specific to the specialized role of the adipocyte in energy homeostasis (33-35).

During embryonic development of adipose tissue, the cell-fate of pluripotent precursor stem cells is at first restricted by largely unknown mechanisms to multipotent mesenchymal stem cells (MSCs). Of mesodermal origin, MSCs can differentiate into a number of tissues including adipose tissue, cartilage, bone and muscle tissue (36). Once MSCs are directed toward the adipocyte lineage via a poorly understood process called "determination," fibroblastic-appearing preadipocytes with the capacity or adipocyte differentiation are formed (Fig 1).

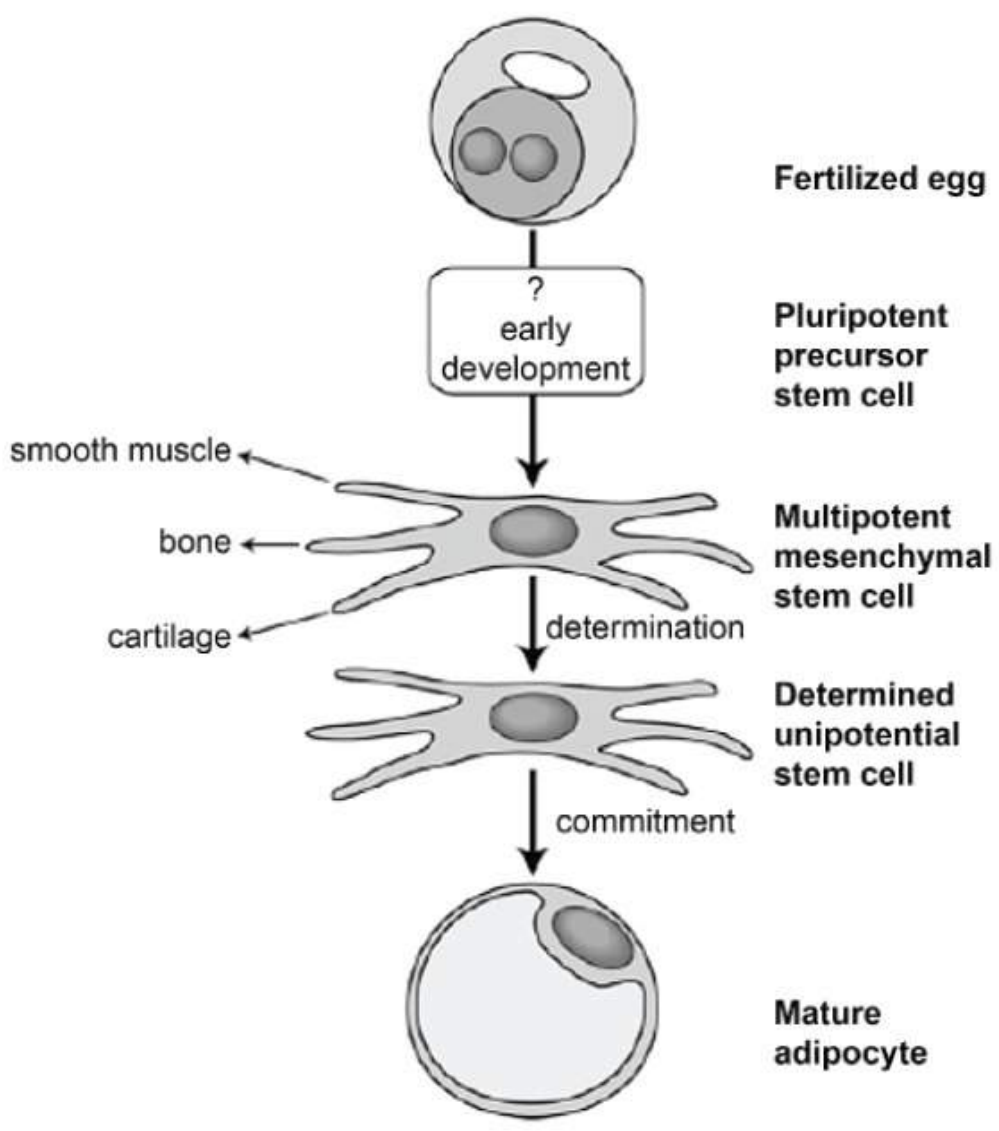

Fig 1. From egg to mature adipocyte (Adapted with permission from Avram MM et al, J Am Acad Dermatol 2007). 
Recently, much attention has been given to the hormones, cytokines, and growth factors that modulate preadipocyte proliferation and adipocyte differentiation in positive or negative ways $(31,34,37-40)$. Much of what is known about these stimulatory and inhibitory regulators has been gleaned from studies using in vitro models of adipogenesis. Widely expressed and secreted by adipocytes, (90) IGF-I is considered the most essential and universally effective paracrine adipogenic signal $(31,42)$. IGF-I promotes both preadipocyte differentiation (43-45) and proliferation $(44,46,47)$.

It has been shown that, both IGF-I and insulin, critical for early adipogenic events, are necessary for adipocyte differentiation induction in vitro and in vivo (43-48). Both hormones mediate their adipogenic effect via a common mechanism, the IGF-I receptor pathway, which represents a complex signaling cascade initiated by activation of the tyrosine kinase IGF-I receptor at the cell surface (45). Once triggered, the IGF-I receptor then, in turn, phosphorylates insulin receptor substrates, which subsequently activate distinct downstream signal transduction pathways with impact on adipogenic gene transcription, such as the upregulation in the expression of PPAR $\gamma$ and $\mathrm{C} / \gamma \mathrm{BP} \alpha$ (49).

Glucocorticoids produce rapid and transient changes in transcription of adipogenic genes during the early stages of differentiation after hormonal induction (50). Most notably, DEX has been shown to induce the expression of C/EBPd in 3T3-L1 cells $(50,51)$, which, in turn, triggers pathways for $\mathrm{C} / \mathrm{EBPa}$-driven differentiation $(52,53)$. DEX also stimulates adipocyte differentiation of human osteoblastic (stromal) stem cells in bone marrow, thereby shifting the balance from bone formation to fat production in the skeletal system and providing a mechanism for steroid - associated osteoporosis. In concert with adipose tissue differentiation in adipose tissue, glucocorticoid-induced adipogenesis from bone marrow stromal cells is mediated through a reaction cascade initiated by transcriptional upregulation of C/EBPd by DEX (55).

The long list of external signals with negative impact on adipogenesis, including growth factors, proinflammatory cytokines, and nutritional signals, have been uncovered (39). In some cases, the inhibitory response is stage dependent. Tumor necrosis factor- $\alpha$ not only inhibits adipocyte differentiation, but also mediates dedifferentiation (10) and apoptosis (56) of mature fat cells. Retinoic acid, the main active form of vitamin $\mathrm{A}$, inhibits both adipocyte proliferation and differentiation (57). Effects of retinoic acid on fat are mediated via retinoic acid receptors, retinoic acid receptor and retinoid $\mathrm{X}$ receptor, both of which are expressed by adipocytes (58).
Intracellular molecular signals and pathways that control adipogenesis have only recently been identified. The extracellular signal-regulated kinase (ERK) pathway, a subset of mitogen-activated protein kinase, plays a particularly prominent role in adipocyte differentiation (59). Preferentially activated by mitogens, such as insulin, ERK kinases provide a bridge between various extracellular signals and the intracellular response. Activation of the ERK pathway yields both positive and negative effects at different stages throughout adipogenesis (59). Stimulation of the ERK pathway is required for the proliferative phase of adipogenesis (60), but must be down-regulated thereafter for effective differentiation. Postmitotic clonal expansion stimulation of the ERK pathway leads to the phosphorylation of $\operatorname{PPAR} \gamma$, which subsequently decreases its transcriptional activity and inhibits adipocyte differentiation (61).

A recently described group of inhibitory proteins, CUP/AP- $2 \alpha$ isoforms 1,3 , and 4 (62), Sp1 (63), CHOP10 (64) and Pref-1 (also known as Dlk1) (65) are expressed by undifferentiated preadipocytes and must be coordinately down-regulated or functionally inactivated after the induction of adipogenesis in order for adipocyte differentiation to proceed. It has been postulated that this class of proteins may function as gatekeepers in vivo, maintaining the preadipocyte phenotype until hormonal and nutritional conditions are supportive for adipocyte differentiation.

An additional gate-keeping system recently described involves the transcription factorsGATA-2 and GATA-3, members of the GATA family of transcription factors, all of which share highly conserved zinc-finger DNA binding domains (66). Unlike the C/EBPs, PPAR $\gamma 2$, and CREB, transcription factors that positively affect adipogenesis, GATA-2 and GATA-3, specifically expressed in white and not brown adipose tissue in vivo, have an inhibitory role in the molecular control of the preadipocyte - adipocyte transition (67). Expression of GATA-2 and GATA-3, restricted to preadipocytes, is subsequently down-regulated upon adipocyte differentiation. Constitutive expression of both GATA-2 and GATA-3 suppresses adipocyte differentiation, thereby trapping cells in a preadipocyte stage, an effect mediated, in part, through direct inhibition of PPAR $\gamma$ transcriptional activity (67) 1 and interference with $\mathrm{C} / \mathrm{EBP}$ function via protein-protein interactions (68).

Intense interest in the mechanisms that drive adipose tissue development has uncovered a particularly important relationship between dietary FAs and adipocyte differentiation in recent years. It is currently well established that diets high in fat induce proliferation and adipocyte differentiation in rodents, thereby increasing 
adipose tissue mass and the tendency for obesity (6971). All dietary FAs, however, do not mediate a universal and consistent proadipogenic effect. Rats fed diets rich in omega-3 PUFAs, and in particular diets consisting of large quantities of fish oil (72), demonstrate decreased adipose tissue growth and reduced tendency toward obesity (7275). In vitro and in vivo evidence shows that PUFAs limit adipocyte differentiation as well as the size of lipid droplets formed in new adipocytes $(74,76,77)$.

At present we do not know which factor(s) regulate(s) turnover in humans. However, a protein previously known because of its role in bone formation, tartrate resistant acid phosphatase (TRAP), could also be involved in this process. TRAP is produced by macrophages as a pro-enzyme that previously was thought to be biologically inactive; after release from macrophages it is cleaved into a biologically active form $(78,79)$.

Some years ago it was demonstrated that obesity is accompanied by a low grade inflammation of adipose tissue with macrophage infiltration as the most prominent histological feature of the inflammation $(80,81)$. It is believed that this inflammation is a defense mechanism against further fat accumulation, because the inflammatory reaction leads to release of cytokines and chemokines in adipose tissue which inhibits adipogenesis and induces insulin resistance of the fat cells (80-82). However, Arner's findings with TRAP (83) and the demonstration of phagocytosis be macrophages in human obese adipose tissue targeting large adipocytes (12) shed new light on the role of macrophages in obese adipose tissue. These cells may keep up the high turnover rate of adipocytes by stimulating adipogenesis through TRAP and by killing old fat cells through phagocytosis. The fact that adipocyte turnover is very dynamic in man and that the body seems to keep the total number of fat cells fixed in adulthood has important implications for both the development of obesity and the ability to maintain a lower body weight after weight loss (27).

The adipose tissue stroma contains blood vessels and other cell types. It is well documented that among the stromal cells, there are preadipocytes that can be induced to differentiate into adipocytes in vitro (84-86). Recent studies have also demonstrated that obesity induces macrophage infiltration of the stroma of adipose tissue $(80,87)$ and that inhibition of angiogenesis reduces adipose tissue mass (88-91). These findings strongly suggest that stromal cells and blood vessels play key roles in adipogenesis and obesity. However, little is known about how adipogenesis proceeds in vivo or the significance and mechanism of the interactions between stromal cells, vascular cells, and adipocytes $(92,93)$.
MicroRNAs (miRNAs) are short noncoding RNAs that regulate gene expression by binding to target mRNAs, which leads to reduced protein synthesis and sometimes decreased steady-state mRNA levels. Although hundreds of miRNAs have been identified, much less is known about their biological function. Several studies have provided evidence that miRNAs affect pathways that are fundamental for metabolic control in higher organisms such as adipocyte and skeletal muscle differentiation (94).

Potential regulators of adipogenesis include microRNAs (miRNAs), which encode an abundant class of $\sim 22$ nucleotide evolutionarily conserved RNAs that control gene expression at the posttranscriptional level by targeting mRNAs for degradation or translational repression or both (95-97).

Xie's results provide the first experimental evidence for miR-103 function in adipose biology. The remarkable inverse regulatory pattern for many miRNAs during adipogenesis and obesity has important implications for understanding adipose tissue dysfunction in obese mice and humans and the link between chronic inflammation and obesity with insulin resistance (98).

The gap junction is an intercellular membrane channel and mediates direct exchange of cytoplasmic small molecules such as ions, cyclic nucleotides, inositol triphosphates, and other small molecules of $<1 \mathrm{kDa}$ between adjacent cells $(99,100)$. Several studies have reported that gap-junctional communication (GJC) is required for the differentiation of myoblasts and osteoblasts (101-107).

The major component of gap junctions is $\mathrm{Cx} 43$ that exists in almost all tissues (108). Consistent with the loss of GJC during adipogenesis, down-regulation of $\mathrm{Cx} 43$ expression is observed in the murine marrow-derived stromal cell line, H-1/A, when the cells were induced to differentiate into adipocytes (109). Therefore, GJC would seem to play some important roles in an early stage of adipocyte differentiation, especially in mitotic clonal expansion. Study by Yanagiya et al show that the blockade of GJC or $\mathrm{Cx} 43$ during an early stage of differentiation inhibited mitotic clonal expansion and adipocyte differentiation (110).

Until recently, it was thought that all adipocytes are derived from a common precursor. It seemed almost obvious that different types of fat cells are closely related. In contrast to white adipose tissue, brown adipose tissue plays an active role in energy expenditure, oxidizing fatty acids produced by triglyceride hydrolysis to generate heat. As the name suggests, brown adipose tissue appears different from white adipose tissue, largely because of the increased number of mitochondria Also, brown adipocytes contain multiple small lipid droplets, whereas 


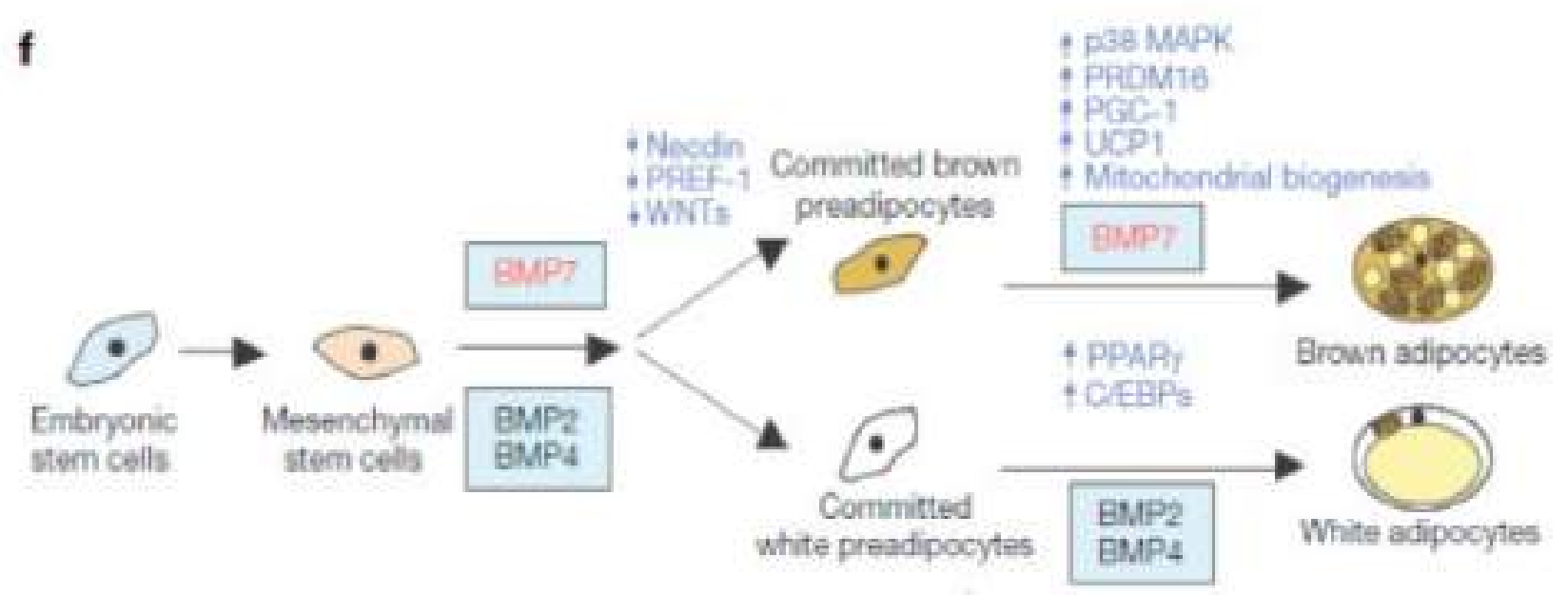

Fig 2. Proposed model for the role of BMPs in datermination of brown versus white adipocyte development (Adapted with permission from Tseng et al, Nature 2006),

white adipocytes ustally have a single large lipid droplet. The themogenic oxidation of fatty acids is facilitated by uncorpling protein-1, which is expressed specifically in brown adipocytes (111).

The link between brown fat and skeletal muscle was ed by the observation that gene-expression protiles Wh adipose tissne share feanures characteristic of skeletal mascle (112).

Many proteins found in brown fat cells - especially those involved in fat optake from the blood, intracellulat fat transport and mitochondrial fat combustion - are more similar to those found in moscle than in white adipose tissue. So the more one thinks about it, the more reasonable it seems that muscle and brown fat cells are closely related. And perhaps we must now look at a brown fat cell as an 'adipomyocyte' - that is, as a muscle cell that has accumnlated fat - rather than as a variety of white fat cell (113).

The central question that must now be addressed is whether BAT function significantly impacts energy balance and human obesity. Classic experiments in rodents have shown that BAT is activated and proliferates in response to overfeeding (114). This so-called "diet-induced adaptive thermogenesis" is an appareat compensatory mechanism to limit excess weight gain and obesity Overfeeding studies in humans have provided evidence for dramatic interindividual differences in the energy cost of feeding (115-117).

The last several years have seen an explosion of information related to the transcriptional control of brown fat cell development, differentiation, and function. The Zn-finger transcriptional regularor PR domain containing 16 (PRDM16) has recently emerged as a dominant driver of brown fat cell fate $(118,119)$. Bone morphogenetic protein 7 (BMP7) was also recently shown to specifically direct brown adipocyte differentiation, inclnding induction of Prdml6 and Ucpl gene expression (120). Synthetic chemicals or endogenous factors (eg., BMP7 itself) that activate PRDM16 function or mimic its action in brown adipocyte development may be viable antiobesity drugs. Altematively, it may be possible to engineer synthetic brown adipocytes ex vivo for antologons transplantation. Of course, it will first be important to establish that these developmental pathways are conserved in human BAT (121).

Nevertheless, the new human data have invigorated interest and excitement in the function and physiological relevance of BAT. Hopefully, these findings can be translated translated into I) a better understanding of the mechanisms that work together to regulate body weight and 2) novel therapentic interventions to reduce the burden of obesity in our society (121). 


\section{Adipocyte Differentiation}

The differentiation of adipocytes represents a complex process dependent on the strict temporal regulation of multiple inhibitory and stimulatory signaling eveats, the net sum of which ultimately leads to the expression of several hundred differentiation-dependent downstream adipocyte-specific and adipocyle-associated genes as well as an increased capacity of the cell for lipid-filling. of lipogenesis $(34,38,122)$. Following initiation of differentiation by a variety of reguisite factors, adipocyte precursor cells express a cascade of transcription factors. transcriptional coactivators, and cell-cycle proteins that each contribute to the regnlation of subsequent steps in the differentiation program. Once triggered, transcription factors act cooperatively and sequentially to promote the necessary stages that drive the adipogenic program. The most prominent of these adipogenic transcription factors, the peroxisome proliferator-activated receptors (PPARs) and OCAAT/enhancer-binding proteins (C/EBPs) (18).

Characterization of regulatory regions of adiposespecific genes has led to the identification of the transcription factors peroxisome proliferator activated receptor $-\gamma$ $(\mathrm{PPAR}-y)$ and $\mathrm{CCAAT}$ /enhancer biting protein (C/EBP). which play a key role in the complex transcriptional cascade during adipocyte differentiation. Growth and differentiation of preadipocytes is controlled by communication between individaal cells of between cells and the extracellular environment, Varions hormones and growth factors thataffect adipocyte differentiation in a positive or negative manner bave been identified. In addition, components involved in cell-cell or cell-matrix interactions such as preadipocyte factor- 1 and extracellular matrix proteins are also pivotal in regulating the differentiation process. Identification of these molecules has yielded clues to the biochemical pathways that ultimately result in transcriptional activation via PPAR- $\gamma$ and CIEBP. Studies on the regulation of the these transcription factors and the mode of action of varions agents that influence adipocyte differentiation will reveal the physiological and pathophysiological mechanisms underlying adipose tissue development (39).

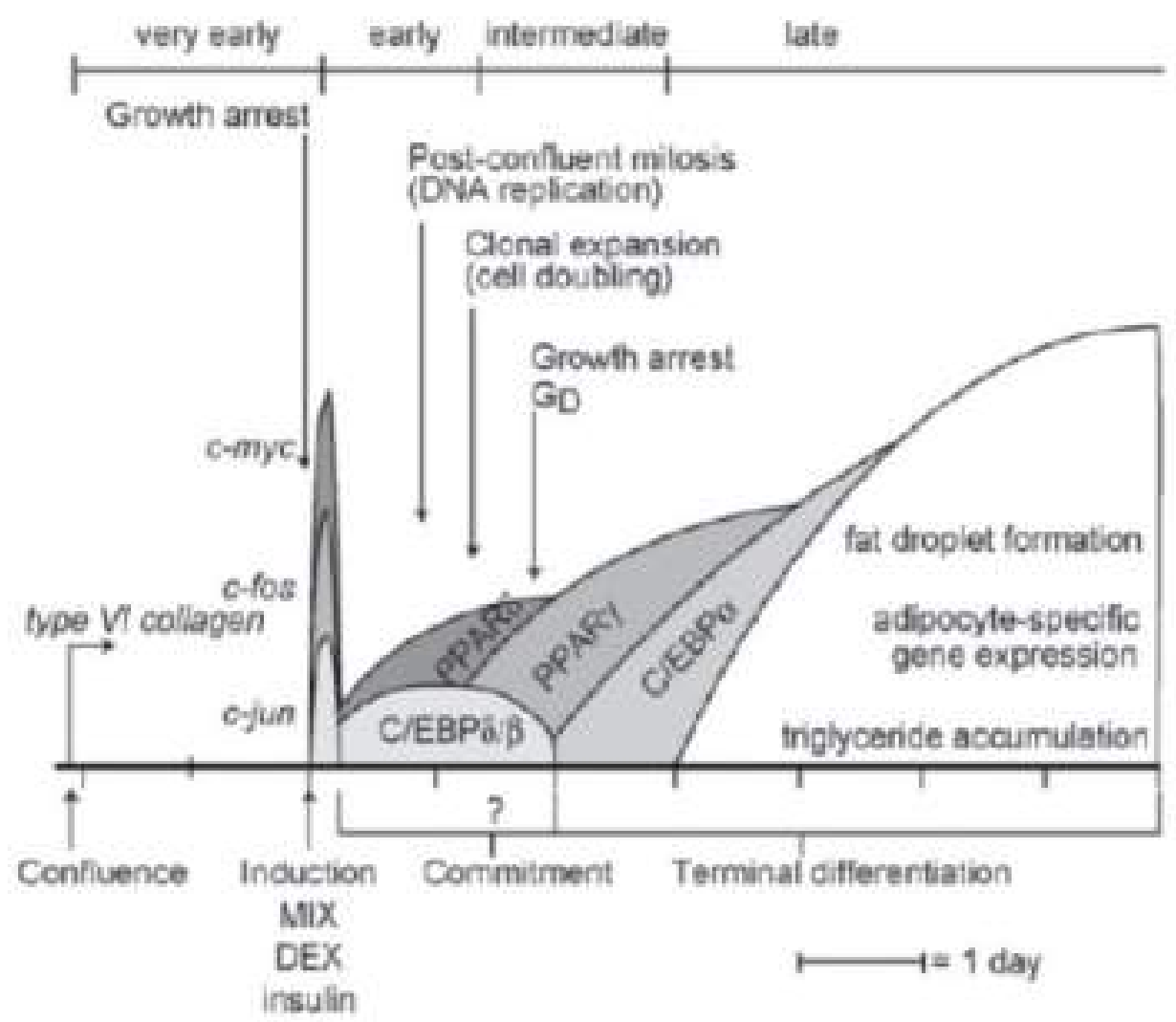

Fig 3. Progression of 3T3 L1 preadpocyte differenfiation (Adepted with permission from Avram MM et al J Am Acad Dermatol 2007). 
The effects of TGF- $\beta$ con the differentiation of varions tissnes of mesenchymal and epithelial origin include both the prevention and induction of expression of specific phenotypes. It las also been observed that TGF $\beta$ inhibits adipoeytogenesis of the munine 3T3-F442A cell line by signaling through Smad 3 (123). Moreover, TGF- $\beta /$ Smad3 has been shown to inhibit the induction of PPAR- $\gamma$ in murine 3T3-F442A and NIH 3 T3 cells (123,124). Despite its ability to inhubit adipocyte differentiation, TGF- $\beta$ is expressed in cultured adipocytes and adipose tissue $(125,126)$. Therefore, there may be endogenous mechanisms that affect TGF- $\beta$ sigualing in adipocyle differentiation.

Horie et al demonstrated that insulin specifically antagonizes TGF- $\beta$ signaling in preadipocytes by stabilizing the putative Smad transcriptional corepressor Triglyceride - interacting factor (TGIF) and regutates adipocyte differentiation (127).

Insulin is a major adipogen. It stimnlates the uptake of glucose, which is then converted into triglycerides and stored in fat droplets leading to adipocyte maturation; insulin also promoces the differentiation of preadipocytes in the stroma of the adipose tissue into adipocytes (128).

Insulin is also known to acutely increase the reactive oxygen species (ROS) production in adipocytes (129), but the enzymes responsible for ROS formation in these cells have not been extensively characterized. Moreover, it is unknown whether ROS are required for insulin-induced differentiation. Besides milochondria, the Nox family of NADPH oxidases is considered the most important source of ROS in the body (130). It is accepted that Noxl-and Nox2-6ependent ROS formation requires activation of the proteins by cytosolic activators, whereas Nox 4 is constitutively active and independent of activator proceins (130.131). It is therefore assumed that Nox 1 and -2 mediate short-term effects, whereas Nox 4 is responsible for logglasting events such as controlling cell cycle progression and proliferation (132).

Nox 4 acts as a switch from insulin-induced proliferation to differentiation by controlling MKP-1 expression, which limits ERKI/2 signaling (133).

The combisation of expression data and functional assay results identified a role for miR.143 in adipocyte differentiation. miR-143 levels increased in differentiating adipocytes, and inhibition of miR-143 effectively inhibited adipocyte differentiation. In addition, protein levels of the proposed miR-143 target ERK5 (4) were tugher in ASO (Antisense Oligonucleotide) - treated adipocytes. These results demonstrate that miR-143 is involved in adipocyie differentiation and may act through tanget geue ERK5 (134).

The zine finger transeription factor GATA-2 and GATA-3 are expressed in adipocyte precursors and control the preadipocyte-to-adipocyte tratsition. Constintive expression of both GATA-2 and GATA-3 suppressed adipocyte differentiation. partially through direct binding to the PPAR r promoter and suppression of its basal activity (68).

Both GATA-2 and GATA-3 form protein complexes with CCAAT/enhancer binding protein alpha (C/EBP $x$ ) and CIEBP $\beta$, menbers of a family of transcription factors that are integral to adipogenesis. This interaction to the basic leucine zipper domain of C/EBPu and a region adjacent to the carbosyl zinc finget of GATA-2. The interaction between GATA and C/EBP factors is critical for the ability of GATA to suppress adipocyte differentiation. Thus in addition to its previously recognized function in suppressing PPAR $\gamma$ transcriptional activity, interaction of GATA factors wirh CEBP is necessaty for their ability to negatively regulate adipogenesis (68)

The process of adipocyte differentiation therefore requires not only cell cycle withdrawal and expression of specic transcription factors, but also a proper extracellndar environment which transdoces external signals to the nucleus via a cascade of intracellular signaling. One such molecnle, preadipocyte factor-1 (pref-1), that onginally cloned by differential screening in an attempt to identify regulatory molecules for adipogenesis (135-138).

Pref- 1 is a transmembrane protein having epiderual growth factor (EGF)-like repeats in the extracellular domain, a juxtamembrane region, a single transmembrane douain, and a short cytoplasmic tail. Pref- $\mathrm{I}$ is found in 3T3L1 preadipocytes but disappears aftet their conversion into adipocytes $(136,139)$. Pref- 1 , therefore, is used as a marker for preadipocytes (140-142). Pref-1 directly activates the MEK/ERK parthway and that ERK ptiosphorylation peaking at day 2 is responsible for Pref- 1 inhibition of adipogenesis (143).

$\alpha-L$ ipoic acid (L.A) has been demonstrated to activate the insulin signaling pathway and to exert insulin-like actions in adjpose and muscle cells. L.A inhibits insulin or the hormonal mixture indnced differentiation of $3 \mathrm{~T} 3 \mathrm{~L}$.1 pre-adipocytes by modulating activity andior expression of pro- or anti-adipogenic transctiption factors mainly through activating the MAPK pathways (144).

The apparent number of preadipocytes in the abdominal selkutaneous tissue that esn undergo differentiation is reduced in obesity with ealarged fat cells, possibly because of increased MAP4K 4(MitogenActivated Protein 4Kinase) levels. TNF-u promoted a macrophage-like phenotype of the preadipocytes, including several macrophage makkers. These results document the plasticity of human preadipocytes and the inverse relationship between lipid storage and proinflammatory capacity (145). 


\section{Adipose Tissue Angiogenesis}

Adipose tissne is highly vascularized, and each adipocyte is nourished by an extensive capillary network (147-149). In vitro studies indicated that depot-dependent vascular traits may be attributable to intrinsic growth characteristics of adjpose tissue endothelial cells. These stuties indicate that adipogenesis may be regulated by factors that drive angiogenesis. Fundamental aspects of angiogenesis, including basement membrane breakdown, vasculogenesis, angiogeaic remodeling, vessel stabilization, and vascular permeability. Critical angiogenic factors include vascular endothelial growth factor (VEGF), VEGF receptors, angiopoietins (Ang), ephrins, matrix metalloproteinases, andthe plasminogenenzymatic system. Vasculat endothelial growth factor is the most critical factor because it initiates the formation of immature vessels and disniption of a single VEGF allele leads to embryonic lethality in mice. Expression of VEGF is influenced by hypoxia, insulin, growth factors, and several cytokives (149).

Vascular endothelial growth factor expression and secretion by adipocytes is regulated by insulin and hypoxia, and is associated with adipose tissue accretion.
Vascular eadothelial growth factor accounts for most of the angiogenic activity of adipose tissue (149).

Growing adipocytes produce a dozen angiogenic factors including leptin, VEGF, FGF-2, HGF, IGF, TNF-1 TGF- $\beta$, placental growth factor (PIGF), VEGF-C, resistin, tissue factor (TF), neuropeptide Y (NPY), beparin-binding epidermal growth factor, and.Angs (150-158). Preadipocytes and adipocytes also produce non-protein small lipid molecules such as monobutyrin that stimulate angiogenesis in the adipose tissue $(159,160) . \mathrm{ASC}$ s secrete high levels of a number of angiogenic factors including VEGF, HGF, GM-CSF, FGF-2, and TGF- $\beta$, (161), Recruitment of inflammatory cells also signifieantly contributes to adipose neovascularization. For example, activated macrophages produce potent angiogenic factors such as TNF- $\alpha$, VEGF. FGF-2, IL-Ib, IL-6, and II-8 (87,162).

Taken together, these findings surport the notion that adipose tissue development reguires constant vasculat remodeling and that multiple angiogenic molecules prodnced in adipose tissue may contribute to the complex regulation of adipogenesis $(163,164)$.

\section{Lipid Droplet Biogenesis}

Most organisnis transpoet or store nevtral lipids as lipid bodies - lipid droplets that usually are bounded by specific. proteins and (phospho)lipids (165). The early phases of lipid-body biogenesis probably proceed by a similar mechanism in white- and brown adipose-tissue adipocytes. Earty in adipocyte differentiation, tascent lipid bodies appear to arise from, and sometimes appear to be eufolded by, ER membranes. Such lipid bodies coutain an $\sim 50-k D a$ surface-bound acylated protein - adipose differentiation related protein (ADRP) - that originally was isolated as a strongly induced marker of adipocyte differentiaticen (166) During the further differentiation of adipoestes, perilipins (a class of 42-56-kDa polypeptides) replace ADRP as the predoninant protein on the surfaces of lipid bodies. The $\mathrm{N}$-terminal 105 residues of the perilipins are similar to ADRP, although perilipins are found only in adipocytes and steroidogenic cells. As in the case of ADRP, perilipin expression is concurrent with lipid-body formation (165). Adipocyte differentiation in white adjpose tissue involves the coalescence of small nascent lipid bodies to form the one or more large TAG droplets found in manure cells. By contrast, most other cell types contain numerous smaller lipid bodies (165).

An endoplasmic reticulum localization of the lipid droplet assembly is consisteat with the observation that microsomal membeane proteins are inyolved in the Dassembly of lipiddroplets. These include phospholipase D1 (PLD1), which is essential for the assembly of lipid droplets $(167,168)$, and enzymes involved in triglyceride biosynthesis - glycerol-3-phosphate acyltransferase (GPAT) $(169 ; 170)$, phosphatidic acid phosphohydrolase (PAP) (171,172) and diacylglycerol acyltransferase (DGAT) $(172,173)$.

The lipid droplets that are formed at isolated microsomal membranes are $0.1-0.4 \mu \mathrm{m}$ in diameter, which is the size of the smallest droplets observed in cells by electron microscopy, and their assembly is totally dependent on the rate of triglyceride biosynthesis (167).

Once formed. lipid droplets are transported on microtulules $(174,175)$. The motor protein dynein has 
been shown to be present on the droplets (175) and sorted to the droplets following phosphorylation by the cytosolic protein extracellular-regulated kinase 2 (ERK2) (176). Both dynein and microtubules are essential for lipid droplet fusion $(168,175)$.

Lipid droplets in the cytosol are several folds larger than the ones formed from the microsomal membranes. the droplets can increase in size by a fusion process that is independent of triglyceride biosynthesis (175). The involvement of $\alpha$-soluble $\mathrm{N}$-ethylmaleimi de-sensitive factor adaptor protein receptors (SNAREs) in the fusion between transport vesicles and target membranes has been described in detail $(176,177)$. A SNARE on the transport vesicle ( $v$-SNARE or R-SNARE) interacts with SNAREs present on the target membrane (t-SNARE or Q-SNAREs) to form a SNARE complex.

After fusion, the SNARE complex is unwound by the ATPase N-ethylmaleimide-sensitive factor (NSF) and its adaptor $\alpha$-soluble NSF adaptor protein ( $\alpha$-SNAP). These SNAREs and $\alpha$-SNAP are essential for the fusion between the droplets. Thus lipid droplets grow in size by a fusion process catalyzed by the SNARE system (179).

Insulin resistance is highly associated with increased accumulation of lipids in skeletal muscle (180-187), and studies have identified SNAP23 as a potential link between insulin resistance and inflow of fatty acids to the cell (179).

Furthermore, it is not the lipid droplets per se that promote the development of insulin resistance but the influence of the fatty acids on SNAP23. This could either be an indirect influence through the insulin signal or a direct influence of the fatty acids on SNAP23 structure or sorting. The effect of fatty acids on the insulin signal is well established (188) and is proposed to be mediated by fatty acid metabolites such as diglycerides $(189,190)$, ceramides (191) and partially oxidized fatty acids (192). The exact mechanism, however, is not known.

Recent evidence suggests that lipid droplets can form tight interactions with other organelles such as peroxisomes, the endoplasmic reticulum, endosomes and mitochondria (192-196). Lipid droplets are proposed to interact with the outer leaflet of the peroxisome membrane (197) that is similar to our proposed model for the fusion between lipid droplets. It would thus be of interest to determine the role of the SNARE system in the interaction between lipid droplets and peroxisomes. The interaction between lipid droplets and the endoplasmic reticulum involves a tethering mechanism rather than a fusion process, and seems to be mediated by the GTPase Rab18 $(192,193)$. Little is known about the interaction with endosomes (which is dependent on Rab5 (195) or with mitochondria (196).
Fat-specific protein of $27 \mathrm{kDa}$ (FSP27) also known as Cidec is a highly expressed adipocyte protein that promotes triglyceride accumulation within lipid droplets. In this issue of the JCI, Nishino et al. show that FSP27 also helps to maintain the characteristically large unilocular lipid droplet structure within each white adipocyte. Fragmentation of lipid droplets in white adipocytes from FSP27-KO mice caused both increased lipolysis and upregulation of genes enhancing mitochondrial oxidative metabolism. This increased energy expenditure in turn protected the mice from diet-induced obesity and insulin resistance. These new results highlight powerful mechanisms that tightly coordinate rates of triglyceride storage in lipid droplets with mitochondrial fatty acid oxidation in white adipocytes (197).

Lipid droplets are dynamic and heterogeneous in size, location, and protein content. The proteins that coat lipid droplets change during lipid droplet biogenesis and are dependent upon multiple factors, including tissuespecific expression and metabolic state (basal vs. lipogenic vs. lipolytic). New data suggest that proteins previously implicated in vesicle trafficking, including Rabs, SNAREs, and motor and cytoskeletal proteins, likely orchestrate the movement and fusion of lipid droplets. Thus, rather than inert cytoplasmic inclusions, lipid droplets are now appreciated as dynamic organelles that are critical for management of cellular lipid stores. (199).

\section{PAT Protein}

In addition to the proteins discussed above, a number of other proteins have been identified on lipid droplets. The most well known of these are the PAT proteins, named after the first identified species perilipin, ADRP and tailinteracting protein 47 (TIP47) (200-202). These proteins contain one PAT domain in the $\mathrm{N}$-terminus and a second in the $\mathrm{C}$-terminus.

Adipophilin also called adipose differentiation-related protein, TIP47 (for Tail-Interacting Protein of $47 \mathrm{kDa}$ ), S312, OXPAT (also called Myocardial Lipid Droplet Protein or MLDP and Lipid Storage Droplet Protein 5 or LSDP5), and LSD1 and LSD2 (for Lipid Storage Droplet proteins 1 and 2 ). And perilipin members of this family share varying levels of sequence similarity, lipid droplet association, and functions in stabilizing lipid droplets (203).

The most recently described member of the perilipin family has been given several names, including OXPAT (for a PAT family protein expressed in oxidative tissues) (203), 
MLDP (204), and LSDP5 (201). OXPAT/MLDP is most highly expressed in heart and slow-twitch muscle, with lower levels in fast-twitch muscle, liver, white and brown adipose tissue, testis, and adrenal gland $(201,203,204)$. OXPAT/MLDP is related to TIP47 (30\% identity) and adipophilin (26\% identity) throughout the amino acid sequence (203).

Furthermore, like TIP47, OXPAT/MLDP is stable in the cytoplasm but is recruited to lipid droplets under conditions that promote lipid droplet formation (203). The two remaining members of the protein family, perilipin and S3-12, have divergent amino acid sequences relative to TIP47, adipophilin, OXPAT/MLDP, and each other.

Three protein isoforms of perilipin have been described that arise from the translation of alternatively spliced mRNA $(205,208)$. Perilipin A is the largest protein (517 amino acids in mice) and the most abundant protein on adipocyte lipid droplets $(206,207)$; perilipin B, a less abundant protein, shares 405 amino acids with perilipin A followed by 17 unique amino acids at the $\mathrm{C}$ terminus (in mice) $(206,207)$; perilipin $C$ is an even shorter isoform that is expressed only in steroidogenic cells $(207,208)$.

Functional studies in cell culture and animal models have demonstrated that perilipin and the related proteins in the perilipin family regulate the lipolysis of stored neutral lipids.

Adipophilin is the major surface protein on the lipid droplets of fibroblasts, but ectopic expression of perilipin A replaces the adipophilin content of the droplets in favor of a perilipin coat $(209,210)$. These data suggest that perilipin A competes with adipophilin for binding to lipid droplets and is more effective at attenuating lipolysis than adipophilin. Loss of adipocyte perilipin content, with the concomitant loss of the protection of stored triacylglycerol from cytosolic lipases, is part of the mechanism by which TNF-a increases lipolysis; the resulting increased flux of fatty acids may contribute to local effects on gene expression within adipocytes as well as to distal effects of fatty acids on insulin sensitivity in other tissues (202).

Under basal conditions, perilipin may bind proteins that facilitate triacylglycerol storage while allowing a low level of lipolysis. When PKA is activated, phosphorylated perilipin disperses the basal coat proteins to make way for powerful lipolytic machinery, including lipases and trafficking molecules, some of which may facilitate the budding off of microlipid droplets (202).

Two examples of perilipin binding proteins have been reported. Hormone-sensitive lipase requires perilipin A to dock on lipid droplets and gain access to lipid substrates after hormonal stimulation of adipocytes, as discussed. An example of a protein that binds to perilipin A under basal conditions is CGI-58, also called ABHD5 (for $\alpha / \beta$ hydrolase fold domain 5) $(211,212)$. C More recent studies suggest that CGI-58 serves as a coactivator of ATGL, stimulating triacylglycerol hydrolysis by as much as 20 fold $(213,214)$.

Gel mobility shift and chromatin immunoprecipitation assays showed that endogenous PPAR $\gamma$ protein binds to the perilipin promoter. PPAR $\gamma 2$, an isoform exclusively expressed in adipocytes, was found to be the most potent regulator from among the PPAR family members including PPAR $\alpha$ and PPAR $\gamma 1$. These results make evident the fact that perilipin gene expression in differentiating adipocytes is crucially regulated by PPAR $\gamma 2$, providing new insights into the adipogenic action of PPAR $\gamma 2$ and adiposespecific gene expression, as well as potential anti-obesity pharmaceutical agents targeted to a reduction of the perilipin gene product (215).

Polymorphisms at the perilipin locus are associated with anthropometric measures and the risk of obesity in a gender specific fashion, in several ethnic groups from different studies including Whites (two studies) $(216,217)$, Malays (218) and Asian Indians (216). The nature of the associations, however depends on the intragenic linkage disequilibrium structure of the perilipin locus in the various populations (220).

Dietary fat may interact with polymorphisms at the perilipin locus to modulate diabetes related traits, data from the Singapore population, taking into consideration dietary macronutrient intake (219). Tai ES et al found evidence of an interaction between dietary fat (specifically saturated fat) intake, polymorphisms at the perilipin locus $(11482 \mathrm{G}>\mathrm{A}$ and $114995 \mathrm{~A}>\mathrm{T}$ ) and insulin resistance (220).

In response to cold, norepinephrine (NE)-induced triacylglycerol hydrolysis (lipolysis) in adipocytes of brown adipose tissue (BAT) provides fatty acid substrates to mitochondria for heat generation (adaptive thermogenesis). NE-induced lipolysis is mediated by protein kinase A (PKA)-dependent phosphorylation of perilipin (221).

Perilipin seems important for the regulation of lipolysis in human fat cells. Obesity and a polymorphism in the perilipin gene associate with decreased protein content of perilipin and increased basal (unstrained) and noradrenaline-induced lipolysis. Low perilipin content also associate with high in vivo lipolytic activity. Perilipin could be a factor behind impaired lipolysis in insulinresistant conditions (222). 


\section{Adipose Tissue Lipolysis}

One of the central reactions in bodily energy metabolism is lipolysis in adipocytes, the reaction that governs the release of stored fatty acids from the adipocyte triacylglycerol pool, which constitutes the major energy reserve in animals. These fatty acids are then transported by serum albumin to various tissues to supply their energy requirements. This reaction was previously thought to result from phosphorylation and activation of hormone-sensitive lipase (HSL) by protein kinase A (PKA) but is now known to be governed by a translocation of the lipase from the cytosol to the surface of the intracellular lipid droplet that houses the reservoir of TAG. This droplet is coated with perilipin A, which is also phosphorylated by PKA in response to lipolytic stimuli, and phosphorylation of perilipin A is essential for HSL translocation and stimulated lipolysis (223).

Release of fatty acids (FAs) from adipose tissue through lipolysis in fat cells is a key event in many processes. FAs are not only energy substrates but also signalling molecules and substrates for lipoprotein production by the liver. Fat cells consist of $>95 \%$ triglycerides that are hydrolysed during lipolysis to glycerol and FAs (224).

In contrast to these "beneficial" characteristics, unesterified FAs can become deleterious for cells when present even at relatively low concentrations. The chronic exposure of nonadipose cells and tissues to elevated concentrations of FAs triggers adverse effects subsumed under the term of "lipotoxicity" $(225,226)$.

The mobilization of FAs from all fat depots depends on the activity of TG hydrolases. Currently, three enzymes are known to hydrolyze TG, the well-studied hormonesensitive lipase (HSL) and monoglyceride lipase (MGL), discovered more than 40 years ago, as well as the relatively recently identified adipose triglyceride lipase (ATGL). The phenotype of HSL- and ATGL-deficient mice, as well as the disease pattern of patients with defective ATGL activity (due to mutation in ATGL or in the enzyme's activator, CGI-58), suggest that the consecutive action of ATGL, HSL, and MGL is responsible for the complete hydrolysis of a TG molecule. The complex regulation of these enzymes by numerous, partially uncharacterized effectors creates the "lipolysome," a complex metabolic network that contributes to the control of lipid and energy homeostasis (227).

Numerous lipolytic and antilipolytic effectors control the catabolism of stored fat in various tissues $(228,229)$. These include hormones, cytokines, and adipokines. In adipose tissue, the most potent stimulatory signals are catecholamines acting on $\beta$-adrenergic receptors (230). In human adipose tissue, only $\beta 1$ and $\beta 2$ receptors induce lipolysis. When catecholamines bind to these receptors, stimulatory Gs proteins activate adenylate cyclase, causing a riseincAMPlevels andelevatedactivity of AMP-dependent protein kinase-A (PKA) $(229,231,232)$. PKA-mediated phosphorlylation of target proteins, including lipolytic enzymes and lipid droplet associated proteins, induces an increased release of FAs and glycerol from adipose tissue up to 100 -fold. Other hormones that stimulate PKA via Gs protein-coupled receptors include glucagon, parathyroid hormone, thyrotropin, $\alpha$-melanocyte-stimulating hormone, and adrenocorticotropin. Several antilipolytic factors have been shown to act through inhibitory Gi protein-coupled receptors (229). These factors include catecholamines acting through $\alpha 2$-adrenergic receptors (230), adenosine (A1-adenosine receptor) (14), prostaglandin (E2 receptor) (234), NPY (NPY-1 receptor) (235), and nicotinic acid (GPR109A receptor) (236). The relative distribution of $\alpha$ and $\beta$-adrenergic receptors therefore determines the lipolytic activity in a tissue- and cell type-specific manner. Insulin and insulin-like growth factor represent the most potent inhibitory hormones in lipolysis $(228,237)$. Their effects are primarily communicated through the insulin receptor (IR), polyphosphorylation of insulin receptor substrates 1-4 (IRS1-4), activation of phosphatidylinositol-3 kinase (PI3K), and the induction of the protein kinase B/ AKT (PKB/AKT). Complexity in this essentially linear pathway is added by the divergence at so-called critical nodes that interact with other signaling cascades (238). Critical nodes in the IR pathway include the IR and IRS interacting with cytokine and extracellular signalregulated kinase (ERK) signaling and PI3K activating both 3-phosphoinositidedependent protein kinases (PDK1 and 2 ) as well as atypical protein kinases $\mathrm{C}(\mathrm{PKCl}$ and $\mathrm{z})$. At this point, a signaling network is established that regulates innumerable biological processes (possibly more than $1,000)$. Lipolysis is affected in multiple steps, including the phosphorylation of phosphodiesterase $3 \mathrm{~B}$, causing the degradation of cAMP and loss of PKA activation (237).

The mechanisms through which other effectors regulate lipolysis are less well characterized. These include tumor necrosis factor- $\alpha$ (TNF $\alpha$ ), growth hormone, the Cide domain-containing proteins (CideN) family of proteins (CIDEA, -B, and -C), and the CopI-ARF vesicle transport machinery described below.

HSL exhibits broad substrate specificity capable of hydolyzing TG, diacylglycerol (DG), monoacylglycerol (MG), cholesteryl esters (CEs), retinyl esters (REs), and other ester substrates such as p-nitrophenyl butyrate (239). The relative maximal hydrolysis rates are in the range of 


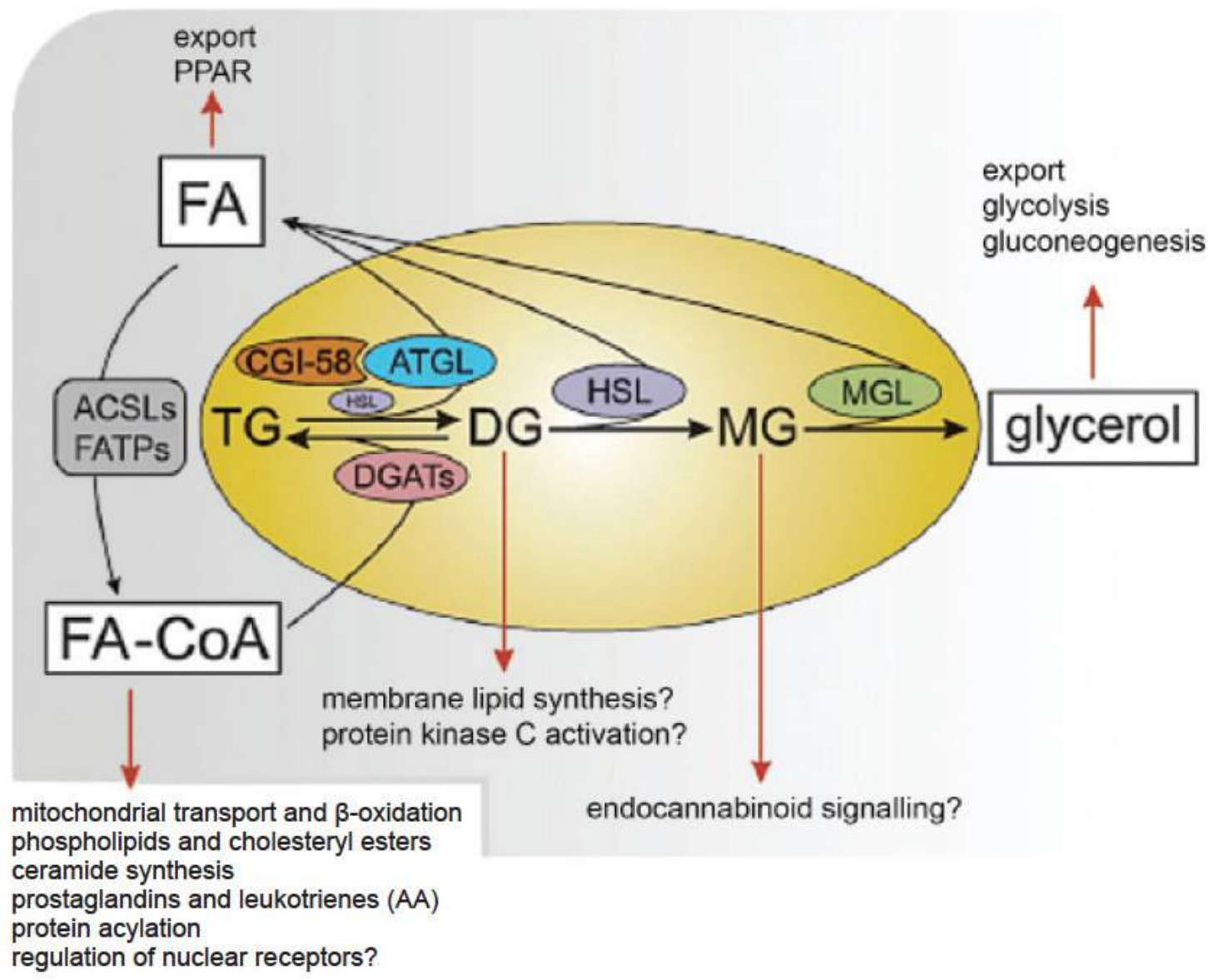

Fig 4. Simplified summary of the lipolytic process and the involved metabolic intermediates (Adapted with permission from Zechner R et al, J Lipid Res 2009).

1: 10: 1: $4: 2$ for TG: DG: MG:CE: RE. Thus, TGs are actually the worst substrate for HSL among all these natural lipid esters, whereas DGs are the best. In 2004, three groups independently published the discovery of an enzyme able to hydrolyze TG and named it ATGL (240), desnutrin (241), or calcium-independent phospholipase A2z (iPLA2z) (242).

ATGL exhibits 10-fold higher substrate specificity for TG than for DG and selectively performs the first step in TG hydrolysis, resulting in the formation of DG and FA (241).

ATGL is most closely related to a group of five genes and proteins named patatinlike phospholipase domaincontaining 1 to 5 (PNPLA1-5) $(243,244)$. Members of this protein family in addition to ATGL (PNPLA2) are PNPLA1, adiponutrin (PNPLA3), GS2 (PNPLA4), and GS2-like (PNPLA5). More distantly related members of ATGL include neuropathy target esterase (NTE, PNPLA6), NTE-related esterase (NRE, PNPLA7), calciumindependent phospholipase A2g (iPLA2g, PNPLA8), and phospholipase A2 group VI (PLA2G6, PNPLA9). Like ATGL, adiponutrin, GS2, and GS2-like also exhibit hydrolase and transacylase activity in in vitro assays (242). Low specific phospholipase activity was reported for ATGL, adiponutrin, and GS2-like $(242,245)$.

A lipid droplet protein, CGI-58 or ABHD5, was found to activate ATGL (213). In the presence of CGI58 , the TG hydrolase activity of mouse ATGL is induced approximately 20 -fold. Human ATGL is also activated by CGI-58, although to a lesser degree (approximately 5 -fold ATGL induction). Importantly, these findings provided a biochemical explanation for a human disorder. In 2001, Lefevre et al. (125) discovered that mutations in the gene for CGI-58 are causative for a lipid storage disorder designated "neutral lipid storage disease" or Chanarin Dorfman Syndrome. The crucial role of perilipin in the ATGL/CGI-58-mediated hydrolysis of TG became evident in an elegant study by Miyoshi et al. (247) showing that hormone stimulated lipolysis depended on perilipin and ATGL. The authors demonstrated that perilipin 
phosphorylation of residue serine-517 is essential for ATGL-mediated lipolysis and represents a prerequisite for the function of subsequent lipase activity of HSL.

In addition to PAT proteins, other proteins found on lipid droplets are also involved in the regulation of lipolysis. Surprisingly, searching for receptors and binding proteins for pigment epithelium derived factor (PEDF), Notari et al. (245) identified ATGL as a PEDF binding protein and proposed to name the enzyme PEDF-receptor. Apparently, ATGL is highly expressed in the pigment epithelium and can be found on the plasma membrane, where it binds to PEDF and exhibits phospholipase activity. Another group of lipid droplet binding proteins that regulate lipolysis belongs to the CideN family. CideN proteins were originally discovered because of their structural similarity to DNA fragmentation factors and were believed to regulate cell death activation (135). Recently, members of the CideN family were shown to affect lipid droplet morphology and turnover. CideA and CideC/Fsp27 bind to lipid droplets and colocalize with perilipin $(248,249)$. Overexpression of these factors inhibits fat catabolism and induces cellular lipid accumulation (249). Consistent with these findings, mice that lack CideC/FSP27 have smaller, multilocular lipid droplets, decreased fat mass, lower levels of plasma FAs, and increased insulin sensitivity $(198,251)$.

Taken together, these results suggest that lipases are embedded in a complex "lipolysome" consisting of the actual lipolytic enzymes and numerous modulators of enzyme activity (227).

Additionally, better understanding of the "lipolysome" might lead to pharmacological treatment controlling the release of FA and other lipolytic products involved in the development of insulin resistance and type 2 diabetes (227).

\section{Adipose Tissue as an Endocrine Organ}

As the master regulator of systemic lipid storage and through secretion of a number of these adipokines, adipose tissue has an influence on many processes, including energy metabolism, inflammation, and pathophysiological changes such as cancer and infectious disease (252). At the interface of energy metabolism and inflammation, adipose tissue also plays a key role in the development of the metabolic syndrome. As such, our views of adipose tissue have changed significantly over the past 20 years. Initially considered an inert storage compartment for triglycerides, pioneering work from the Spiegelman and Flier (253) laboratories in the mid-1980s highlighted for the first time that adipocytes are an abundant source of a specific secretory protein, called adipsin or complement factor D. In 1995, Jeffrey Friedman's (254) group identified leptin as a fat cell-specific secretory factor deficient in the ob/ ob mouse that mediates the hormonal axis between fat and the brain.

Around the same time, we and others described a protein that initially termed Acrp30, which later became known as adiponectin (255-258). Additional proteins have joined this exclusive club of adipocyte-specific secretory proteins since then, including adipokines such as resistin $(259,260)$ and acylation-stimulating protein $(261)$, as well as the recently described visfatin $(262,263)$ and retinolbinding protein-4 (264). Enzymes such as lipoprotein lipase are also abundantly produced and released from adipocytes. Finally, many proinflammatory cytokines and acute phase reactants originate in the adipocyte. These include $\alpha 1$ acid glycoprotein, serum amyloid A, the C-reactive protein homolog pentraxin-3, the lipocalin $24 \mathrm{p} 3$, and a host of cytokines (265).

Using adipokines as one of the major communication tools, adipocytes affect a large number of other tissues, such as the liver, muscle, the brain, the reproductive system, pancreatic $\beta$-cells, and, as mentioned above, the vasculature (266).

It is now clear that adipose tissue is a complex and highly active metabolic and endocrine organ $(267,268)$. Besides adipocytes, adipose tissue contains connective tissue matrix, nerve tissue, stromovascular cells, and immune cells (14). Although adipocytes express and secrete several endocrine hormones such as leptin and adiponectin, many secreted proteins are derived from the nonadipocyte fraction of adipose tissue (269). Regardless, these components function as an integrated unit, making adipose tissue a true endocrine organ (14).

As a further level of complexity, there is considerable heterogeneity among the various adipose tissue depots. The sc and visceral adipose tissue depots have been the best characterized, particularly with respects to contribution to disease. Visceral adipose tissue is associated with increased risk for multiple medical morbidities including the metabolic syndrome. This observed difference in disease risk may be due to differences in endocrine function among adipose tissue depots. The anatomic location of 
each adipose tissue depot itself affects endocrine function. Endocrine hormones derived from visceral adipose tissue are secreted into the portal system and have direct access to the liver, whereas those derived from sc adipose tissue are secreted into the systemic circulation. Hence, the former have a relatively greater effect on hepatic metabolic function (270).
So far, many adipokines have been identified (Table 1). They all integrate in a communications network with other tissues and organs such as the skeletal muscle, adrenal cortex, brain and sympathetic nervous system and participate in appetite and energy balance, immunity, insulin sensitivity, angiogenesis, blood pressure, lipid metabolism and haemostasis (271).

Table 1. Adipokines and their main effects (271).

\begin{tabular}{|c|c|}
\hline Parameter & Effects on \\
\hline LPL & Lipid metabolism \\
\hline HSL & Lipid metabolism \\
\hline Perilipin & Lipid metabolism \\
\hline aP2 & Lipid metabolism \\
\hline CETP & Lipid metabolism \\
\hline RBP4 & Lipid metabolism, insulin resistance \\
\hline IL-6 & Inflammation, atherosclerosis, insulin resistance \\
\hline TNF- $a$ & Inflammation, atherosclerosis, insulin resistance \\
\hline Adipsin/ASP & Immune - stress response \\
\hline Metallothionein & Immune - stress response \\
\hline Angiotensinogen & Vascular homeostasis \\
\hline $\mathrm{PAI}-\mathrm{I}$ & Vascular homeostasis \\
\hline Adiponectin & Inflammation, atherosclerosis, insulin resistance \\
\hline PPAR-y & Lipid metabolism, inflammation, Vascular homeostasis \\
\hline CRP & Inflammation, atherosclerosis, insulin resistance \\
\hline IGF-1 & Lipid metabolism, insulin resistance \\
\hline TGF- $\beta$ & Cell adhesion and migration, growth and differentiation \\
\hline Monobutyrin & vasodilation of the microvessel \\
\hline Uncoupling proteins & Energy balance and thermoregulation \\
\hline Steroid hormones & Lipid metabolism, insulin resistance \\
\hline Leptin & Food regulation, reproduction, angiogenesis, immunity \\
\hline Resistin & Inflammation, insulin resistance \\
\hline P450 arom & Lipid metabolism \\
\hline Apelin & Insulin resistance \\
\hline Visfatin & Insulin resistance \\
\hline Vaspin & Insulin resistance \\
\hline ZAG & Lipid metabolism, cancer cachexia. \\
\hline
\end{tabular}

Abbreviations: LPL, lipoprotein lipase; HSL, hormone-sensitive lipase; aP2, adipocyte lipid-binding protein; RBP, retinol-binding protein; IGF-1, insulin-like growth factor-1; TGF- $\beta$, transforming growth factor- $\beta$; PPAR- $y$, peroxisome proliferator-activated receptor y; ZAG, zinc-a2-glycoprotein. 
Over $90 \%$ of adipokine release by adipose tissue, except for adiponectin and leptin, was due to nonfat cells. Although PAI-1 was released to the medium by adipocytes in amounts $30 \%$ of that by the tissue matrix the release of all other adipokines by adipocytes was less than $15 \%$ of that by the tissue matrix. Furthermore, the greater release of VEGF, IL-6, and PAI-1 by visceral adipose tissue as opposed to abdominal sc adipose tissue was due to the nonfat cells of the tissue (269).

The concentration in blood of many adipokines, hormones, and acute-phase proteins is altered in human obesity. Leptin is elevated, whereas plasma adiponectin is reduced in obese humans $(14,267,272-275))$. C-reactive protein (CRP) (276-282) is an example of an acute-phase protein whose circulating level is higher in obese than in nonobese individuals. Blood levels of $\mathbb{I L}-10$ (282), IL-6 (278-286), IL-8 $(285,287)$, plasminogen activator inhibitor 1 (PAI-1) $(284,288-291)$, TNF- $\alpha(278,292)$, and hepatocyte growth factor (HGF) (293) have all been reported to be elevated in obesity.

Adipocyte size is an important determinant of adipokine secretion. There seems to be a differential expression of pro- and antiinflammatory factors with increasing adipocyte size resulting in a shift toward dominance of proinflammatory adipokines largely as a result of a dysregulation of hypertrophic, very large cells (294).

The existence of a network of adipose tissue signaling pathways, arranged in a hierarchical fashion, constitutes a metabolic repertoire that enables the organism to adapt to a wide range of different metabolic challenges, such as starvation, stress, infection, and short periods of gross energy excess (268). Unraveling the diverse hormonal and neuroendocrine systems that regulate energy balance and body fat has been a long-standing challenge in biology, with obesity as an increasingly important public health focus (295).

\section{Adipocyte Dysfunction}

Abdominal obesity and adipose tissue dysfunction are major risk factors for chronic diseases, such as insulin resistance, type 2 diabetes, and cardiovascular diseases. Insulin resistance is associated with alterations in glucose and lipid homeostasis. During the genesis of obesity, adipose tissue is one of the first tissues affected by insulin resistance. This phenomenon is closely associated with the development of a proinflammatory state within the adipose tissue. In addition to this proinflammatory state, obesity is associated with the formation of hypoxic areas within the tissue (296).

Obesity-associated inflammation leads to highly dysregulated adipose tissue with an altered pattern of secreted adipokines and increased lipolysis $(297,298)$. Secretion of cytokines like tumor necrosis factor (TNF)- $\alpha$ in the adipose tissue impairs the differentiation of preadipocytes, reduces adiponectin secretion, and promotes a proinflammatory state, which in turn further promotes the local secretion of cytokines and chemokines $(299,300)$. In addition, both interleukin (IL)- 6 and TNF- $\alpha$ induce insulin resistance in the adipose cells at the level of insulin signaling and action because of reduced expression of insulin receptor substrate-1 and GLUT4 $(299,301)$.

Obesity, both in animal models and in humans, is associated with an increase in different markers of inflammatory cells, suchasCD68, macrophageinflammatory protein (MIP)-1 $\alpha$, EMR (epidermal growth factor-like module containing mucin-like hormone receptor), and ADAM-8 (a disintegrin and metalloproteinase domain-8) in the adipose tissue $(297,300,302)$. In fact, using such markers, Weisberg et al. (80) reported that up to $50 \%$ of the cells in the adipose tissue were positive for CD68 and thus could be classified as macrophages. They also reported that the CD68-positive cells were the major producers of the different cytokines studied $(80,145)$.

Obesity as excess of adipose tissue is attributed to hypertrophy and hyperplasia of adipocytes. Adipocytes become hypertrophic during the development of obesity, and their size increases up to $140-180 \mu \mathrm{m}$ in diameter (303). Adipocytes have a limited capacity for hypertrophy; one reason for this is considered the diffusion limit of oxygen, which is at most $100 \mu \mathrm{m}$ (304). Therefore, it is possible that hypertrophic adipocytes might endure less than adequate oxygen supply. Hypoxia occurs when oxygen availability does not match the demand of the surrounding tissue, resulting in decreased oxygen tension (26).

An important and well-characterized key regulator of the adaptive response to alterations in oxygen tension is hypoxia-inducible factor-1 (HIF1), a transcription factor that accumulates during hypoxia and increases the mRNA expression of a wide variety of genes that stimulate erythropoiesis, angiogenesis, and glycolysis (305). On the other hand, hypoxic cells also provoke HIF1-independent adaptive responses. Previous reports have shown that the unfolded protein response (UPR), an HIF1-independent signaling pathway, is activated in the presence of hypoxia and contributes to cellular adaptation of this stress (26).

Many disturbances including hypoxia cause accumulation of unfolded proteins in the ER, resulting in 
ER stress. To cope with the ER stress, cells trigger a set of pathways known as UPR, which is mediated by three types of ER-transmembrane proteins, inositol-requiring protein-1 (IRE1), RNA-dependent protein kinase-like ER eukaryotic translation initiation factor $2 \alpha$ kinase (PERK), and activating transcription factor 6 (ATF6) (306).

Exposure of adipocytes to hypoxia elicits dysregulated production of adipocytokines and that hypoxia-induced downregulation of adiponectin mRNA is mediated by ER stress-dependent transcriptional and -independent posttranscriptional mechanisms (26). Dysregulated production of adipocytokines is associated with the pathophysiology of obesity-related metabolic diseases (307-311).

It is imperative to understand the alterations that occur from the life of a healthy adipocyte to a hypertrophic insulinresistant adipocyte to perhaps even a dead adipocyte. A deeper knowledge of adipose tissue expansion and the dysfunction that follows will be critical to our thinking and to therapy in the coming years (312).

\section{Obesity, Inflammation and Insulin Resistance}

Obesity-associated insulin resistance is a major risk factor for type 2 diabetes and cardiovascular disease. In the past decade, a large number of endocrine, inflammatory, neural, and cell-intrinsic pathways have been shown to be dysregulated in obesity. Although it is possible that one of these factors plays a dominant role, many of these factors are interdependent, and it is likely that their dynamic interplay underlies the pathophysiology of insulin resistance. Understanding the biology of these systems will inform the search for interventions that specifically prevent or treat insulin resistance and its associated pathologies (313).

The complex processes linking obesity to its deleterious health consequences are finally being unraveled. Inflammation is receiving increased attention for its potential role in the pathogenesis of disorders ranging from insulin resistance and type 2 diabetes to fatty liver and cardiovascular disease (314).

Hotamisligil et al. (307) were the first to describe a molecular connection between inflammation and obesity, when TNF- $\alpha$ (tumor necrosis factor- $\alpha$ ), an inflammatory cytokine, was found to be expressed in adipose tissue in obesity animal models.

This inflammatory state is characterized by an increase in macrophage numbers and expression of macrophage markers, such as CD68 $(80,81)$. Expression of insulin-resistance genes and the local production of their protein products by macrophages in adipose tissue are also increased in obese compared with non-obese subjects (6). These and other changes may contribute to increased lipolysis and adiponectin deficiency which characterize adipose tissue of insulin-resistant subjects and may increase liver fat content (315).

Starting with the discovery of leptin in 1994 and subsequently of many other adipokines, adipose tissue has been identified as an endocrine organ, leading to the first revolution in adipose tissue biology (270). The second revolution in adipose tissue biology was the identification of adipose tissue as an organ at the interface of inflammation, insulin resistance, and cardiovascular disease. Moreover, in the past 5 years obesity has been shown to be associated with a low-grade state of inflammation, resulting from increased adipocyte activity and increased immune cell infiltration of adipose tissue $(316,317)$, which may induce insulin resistance and other manifestations of metabolic syndrome as cardiovascular disease (318-320).

Activation of macrophages infiltrating adipose tissue leads to the release of a variety of chemokines and proinflammatory cytokines that initiate a paracrine process with the activation of proinflammatory pathways, contributing to the propagation of additional macrophage recruitment (332). An interesting hypothesis regarding the causes of macrophage infiltration of adipose tissue is that macrophages are recruited to phagocytose dead or dying adipocytes present in the expanding adipose tissue depot. Cinti et al. (12) have recently shown that more than $90 \%$ of macrophages infiltrating the adipose tissue of obese humans and animals are present around dead adipocytes, forming characteristic elements called crownlike structures (CLS). Recently, the same authors described a significantly higher proportion of CLS in the visceral as opposed to subcutaneous depots of genetically obese mice (321).

Clearance of dead adipocytes by ATM $\Phi$ s is an initial remodeling event required for $\mathrm{AT}$ repair and differentiation of new adipocytes at sites of adipocyte loss. MФ-mediated cell killing is a feature of various forms of tissue remodeling (322), rendering it plausible that ATMФs actively participate in adipocyte execution (12). The clearance of dead adipocytes is likely to promote proinflammatory ATM $\Phi$ 
activation, reflecting both the necrotic-like morphology of adipocyte death and ATM $\Phi$ fusion (22). M $\Phi$ fusion, which synergistically increases $M \Phi$ absorptive capacity, requires TNF- $\alpha$ autocrine/paracrine signaling (323), suggesting that CLS and multinucleate giant cells (MGCs) may be chronic sources of TNF- $\alpha$. Moreover, because each dead adipocyte "recruits" dozens of ATMФs, a low frequency of adipocyte death may be sufficient to cause AT inflammation and promote insulin resistance. Excess nutrient intake is the main cause for obesity, and several recent studies have implicated ER stress as an early consequence of nutrient excess and a cause for the development of insulin resistance and inflammation (325).

The adipose tissue has to take up and store excess calories as fat and, hence, needs to synthesize many proteins to meet this challenge. In addition, the massive expansion of adipose tissue requires synthesis of structural proteins. Fatty acids, which are an important part of overnutrition and which have been shown to induce ER stress in cultured hepatocytes and pancreatic $\beta$-cells (326), are likely to be among the agents causing ER stress. ER stress has been demonstrated to trigger activation of several serine/ threonine kinases, including $\mathrm{c}$-jun $\mathrm{NH} 2$-terminal kinase (JNK) and I $x$ B- $\alpha$ kinase (IKK). For instance, ER stress leads to formation of the IRE- $1 \alpha$-TRAF 2 complex, which results in phosphorylation and activation of IKK. IKK phosphorylates and inactivates $\mathrm{I} \alpha \mathrm{B}-\alpha$ resulting in activation and nuclear translocation of nuclear factor $\chi \mathrm{B}$, which is a key promoter of inflammation (327). The IRE-1 $\alpha$-TRAF 2 complex also phosphorylates and activates JNK, which induces the expression of proinflammatory cytokines and induces insulin resistance via serine phosphorylation of insulin receptor substrates 1 and 2 (328). ER stress is also a major source for the production of reactive oxygen species (ROS). This can occur via activation of protein disulfide isomerase (PDI), an enzyme which catalyzes disulfide bridge formation and in the process generates ROS. ROS are known to promote insulin resistance and inflammation $(327,329)$. Thus, the ER may be a proximal site that senses nutritional excess and translates it into metabolic and inflammatory responses. Adipogenesis is associated with changes in amount and subunit composition of the NF- $x \mathrm{~B}$ complexes. NF- $x$ B subunits p65 (RelA), p68 (RelB), and IéB are upregulated during fat cell differentiation (330).

The discovery that obesity also activates intracellular pathways, including the IKK- $\beta-\mathrm{NF}-\boldsymbol{\gamma B}$ and JNK pathways $(328,331)$ added fuel to the inflammatory hypothesis. Upregulation of the IKK- $\beta-N F-\chi B$ axis leads to excess production of multiple potential mediators of inflammation, whereas JNK activation impinges upon insulin signaling through phosphorylation of serine residues of insulin receptor substrate-1. Stimuli potentially activating both IKK- $\beta-N F-\gamma B$ and JNK in obesity can be separated into extracellular ligands, such as the proinflammatory cytokines TNF- $\alpha, \mathrm{IL}-1 \beta$ and IL- 6 or fatty acids binding to Toll-like receptors, and intracellular stimuli such as endoplasmic reticulum or oxidative stress, and ceramides (318). Determining which processes initiate obesity induced inflammation is an active area of investigation (314).

In conclusion, chronic tissue inflammatory responses may be part of a physiologic purpose, as adaptive restoration of tissue homeostasis in response to cellular stress. However, this response often becomes chronic in obesity, where the pathophysiological consequences of chronic adipose tissue inflammation result in insulin resistance (332).

\section{Prediapocyte Plasticity}

Preadipocytes are present throughout adult life in adipose tissues and can proliferate and differentiate into mature adipocytes according to the energy balance. An increasing number of reports demonstrate that cells from adipose lineages (preadipocytes and adipocytes) and macrophages share numerous functional or antigenic properties (333).

Recent studies suggest that preadipocyte and macrophage phenotypes are very similar and that preadipocytes have the potential to be very efficiently and rapidly converted into macrophages. This work emphasizes the great cellular plasticity of adipose precursors and reinforces the link between adipose tissue and innate immunity processes (333).

The emerging field of regenerative medicine will require a reliable source of stem cells in addition to biomaterial scaffolds and cytokine growth factors. Adipose tissue represents an abundant and accessible source of adult stem cells with the ability to differentiate along multiple lineage pathways (334).

Adipose tissue is now also regarded as a promising source of adult stem cells, as adipose tissue has plenty of progenitor cells, some of which can differentiate into diverse lineages (84). A component of fibroblast - like stromal cells obtained from liposuction aspirates can differentiate into various cell lineages (84), including adipogenic, osteogenic (334), chondrogenic (335), myogenic (337), cardiomyogenic (337), and neurogenic (338), thus, adipose tissue - derived stromal cells are now called adipose - derived stem/stromal/progenitor cells (ASCs) and are expected to become a valuable tools for a wide range of cell - based therapies (339). 
ASCs are currently being used in some clinical trials, including treatments for bone defects (autologous fresh ASCs) (340), rectrovaginal fistula (atulogous cultured ASCs) (341), graft - versus - host disease (nonautologous ASCs) (342), and soft tissue grafting (autologous fresh ASCs) (343-346). ASCs have been found to have potential similarities to bone marrow - derived mesenchymal stem cells and are now of great interest as a tool for cell therapies (347).

\section{Conclusions}

During the last decade, understanding the biology of adipose tissue and, in particular, its secretory functions have dramatically improved, and this has completely modified our understanding of the pathophysiological link between the increase of fat mass, namely obesity, insulin resistance and cardiovascular complications.

As our understanding of the integrative biology of adipose tissue increases, we hope that these, and many other aspects of adipose tissue function, will be clarified.

\section{References:}

1. Van Gaal LF, Mertens IL, De Block CE. Mechanisms linking obesity with cardiovascular disease. Nature 2006; 444: $875-880$.

2. Kahn SE, Hull RL, Utzschneider KM. Mechanisms linking obesity to insulin resistance and type 2 diabetes. Nature 2006; 444: $840-846$.

3. Olshansky SJ, Passaro DJ, Hershow RC, Layden J, Carnes BA, Brody $\mathrm{J}$, et al. A Potential decline in life expectancy in the United States in the 21st century. N EnglJ Med 2005; 352: $1138-1145$.

4. Bjorntorp, P. Effects of age, sex, and clinical conditions on adipose tissue cellularity in man. Metabolism 1974; 23 : 1091-1102.

5. Hirsch J, Batchelor B. Adipose tissue cellularity in human obesity. Clin Endocrinol Metab. 1976; 5: 299-311.

6. Trayhurn P. Adipocyte Biology. Obes Rev 2007; 8 (suppl. 1): $41-44$.

7. Spalding KL, Arner E, Westermark PO, Bernard S, Buchholz $\mathrm{BA}$, Bergmann $\mathrm{O}$, et al. Dynamics of fat cell turnover in humans. Nature 2008; 453: $783-787$.

8. Prins JB, O'Rahilly S. Regulation of adipose cell number in man. Clin Sci (Lond) 1997; 92: 3-11.

9. Rodriguez AM, Elabd C, Amri EZ, Ailhaud G, Dani,C. The human adipose tissue is a source of multipotent stem cells. Biochimie 2005; 87: 125-128.

10. Petruschke $T$, Hauner $H$. Tumor necrosis factor- $\alpha$ prevents the differentiation of human adipocyte precursor cells and causes delipidation of newly developed fat cells. J Clin Endocrinol Metab 1993; 76: 742-747.
11. Prins JB, Walker NI, Winterford CM, Cameron DP. Apoptosis of human adipocytes in vitro. Biochem Biophys Res Commun 1994; 201: 500-507.

12. Cinti S, Mitchell G, Barbatelli G, Murano I, Ceresi E, Faloia $\mathrm{E}$, et al. Adipocyte death defines macrophage localization and function in adipose tissue of obese mice and humans. J Lipid Res 2005; 46: 2347-2355.

13. Frayn $\mathrm{KN}$. Adipose tissue as a buffer for daily lipid flux. Diabetologia 2002; 45: 1201 - 1210.

14. Frayn KN, Karpe F, Fielding BA, Macdonald IA, Coppack SW. Integrative physiology of human adipose tissue. Int J Obes 2003; $27: 875-888$.

15. Okuno A, Tamemoto H, Tobe K, Ueki K, Mori Y, Iwamoto K, et al. Troglitazone increases the number of small adipocytes without the change of white adipose tissue mass in obese Zucker rats. J Clin Invest 1998; 101:1354-1361.

16. Hallakou S, Doaré L, Foufelle F, Kergoat M, Guerre-Millo M, Berthault MF, et al. Pioglitazone induces in vivo adipocyte differentiation in the obese Zucker fa/fa rat. Diabetes 1997; 46:1393-1399.

17. Danforth E Jr. Failure of adipocyte differentiation causes type II diabetes mellitus? Nat Genet 2000; 26:13

18. Avram MM, Avram AS, James WD. Subcutaneous fat in normal and diseased state. 3. Adipogenesis: from stem cell to fat cell. J Am Acad Dermatol 2007; 56: 472 - 492.

19. Bray MS, Young ME. Circardian rhythms in the development of obesity: potential role for the circadian clock within the adipocyte. Obes Rev 2006, 8: $169-181$.

20. Edery I. Circadian rhythms in a nutshell. Physiol Genomics 2000; 3: $59-74$.

21. Engfeldt $P$, Arner $P$. Lipolysis in human adipocytes, effects of cell size, age and of regional differences. Horm Metab Res 1988; Suppl 19:26-29.

22. Despres JP, Fong BS, Julien $P$, Jimenez J, Angel A. Regional variation in HDL metabolism in human fat cells: effect of cell size. Am J Physiol 1987; 252:E654-E659.

23. Weyer C, Foley JE, Bogardus C, Tataranni PA, Pratley RE. Enlarged subcutaneous abdominal adipocyte size, but not obesity itself, predicts type II diabetes independent of insulin resistance. Diabetologia 2000; 43:1498-1506.

24. Trayhurn $P$, Wood IS. Adipokines: inflammation and the pleiotropic role of white adipose tissue. $\mathrm{Br} \mathrm{J}$ Nutr 2004: 92:347-355.

25. Hauner $\mathrm{H}$. Secretory factors from human adipose tissue and their functional role. Proc Nutr Soc 2005; 64:163-169

26. Hosogai N, Fukuhara A, Oshima K, Miyata Y, Tanaka S, Segawa K, et al. Adipose tissue hypoxia in obesity and its impact on adipocytokine dysregulation. Diabetes 2007; 56: $901-911$.

27. Arner P. New aspects on adipogenesis in man. Obes Metab 2009; 5 (suppl 2): $32-37$

28. Garaulet M, Hernandez-Morante JJ, Lujan J, Tebar FJ, Zamora S. Relationship between fat cell size and number and fatty acid composition in adipose tissue from different fat depots in overweight obese humans. Int $\mathrm{J}$ Obes (London) 2006; 6: 899-905

29. Faust IM, Johnson PR, Stern JS, Hirsch J. Diet-induced adipocyte number increase in adult rats: a new model of obesity. Am J Physiol 1978; 235: E279-E286.

30. Johnson PR, Stern JS, Greenwood MRC, Hirsch J. Adipose tissue hyperplasia and hyperinsulinemia in Zucker obese female rats: a developmental study. Metabolism 1978; 27 : 1941-1954.

31. Hausman DB, DiGirolamo M, Bartness TJ, Hausman GJ, Martin RJ. The biology of white adipocyte proliferation. Obesity Rev 2001; 2: 239-254. 
32. Gregoire F. Adipocyte differentiation: from fibroblast to endocrine cell. Exp Biol Med 2001; 226: 997-1002.

33. Fajas L. Adipogenesis: a cross-talk between cell proliferation and cell differentiation. Ann Med 2003; 35: 79-85.

34. Smas CM, Sul HS. Control of adipocyte differentiation. Biochem J 1995; 309: 697-710.

35. Ailhaud G, Grimaldi P, Negrel R. Cellular and molecular aspects of adipose tissue development. Annu Rev Nutr 1992; 12: 207-233.

36. Pittenger MF, Mackay AM, Beck SC, Jaiswal RK, Douglas R, Mosca JD, et al. Multilineage potential of adult human mesenchymal stem cells. Science 1999; 284: 143-147.

37. Rosen ED, Spiegelman BM. Molecular regulation of adipogenesis. Annu Rev Cell Dev Biol 2000; 16: 145171.

38. Morrison RF, Farmer SR. Hormonal signaling and transcriptional control of adipocyte differentiation. J Nutr 2000; 130(Suppl): S3116-S3121.

39. Gregoire FM, Smas CM, Sul HS. Understanding adipocyte differentiation. Physiol Rev 1998; 78: 783-809.

40. Sul HS, Smas C. Positive and negative regulators of adipocyte differentiation. J Nutr Biochem 1993; 4: 554-562.

41. Gaskins HR, Kim J-W, Wright JT, Rund LA, Hausman GJ. Regulation of insulin-like growth factor-I ribonucleic acid expression, polypeptide secretion, and binding protein activity by growth hormone in porcine preadipocyte cultures. Endocrinology 1990; 126: 622-630.

42. Marques BG, Hausman DB, Latimer AM, Kras KM, Grossman $\mathrm{BM}$, Martin RJ. Insulin-like growth factor I mediates highfat diet-induced adipogenesis in Osborne-Mendel rats. Am J Physiol 2000; 278: R654-R662

43. Deslex S, Negrel R, Ailhaud G. Development of a chemically defined serum-free medium for differentiation of rat adipose precursor cells. Exp Cell Res 1987; 168: 15-30.

44. Ramsay TG, White ME, Wolverton CK. Insulin-like growth factor 1 induction of differentiation of porcine preadipocytes. J Anim Sci 1989; 92: 2452-2459.

45. Smith PJ, Wise LS, Berkowitz R, Wan C, Rubin CS. Insulinlike growth factor- 1 is an essential regulator of the differentiation of 3T3-L1 adipocytes. J Biol Chem 1988; 263: 9402-9408.

46. Wright JT, Hausman GJ. Insulin-like growth factor-I (IGF-I)induced stimulation of porcine preadipocyte replication. In Vitro Cell Dev Biol 1995; 31: 404-408.

47. Rajkumar K, Modric T, Murphy LJ. Impaired adipogenesis in insulin-like growth factor binding protein-1 transgenic mice. J Endocrinol 1999; 162: 457-465.

48. Holzenberger M, Hamard G, Zaoui R, Leneuve P, Ducos B, Beccavin $C$, et al. Experimental IGF-I receptor deficiency generates a sexually dimorphic pattern of organ-specific growth deficits in mice, affecting fat tissue in particular. Endocrinology 2001; 142: 4469-4478.

49. Miki H, Yamauchi T, Suzuki R, Komeda K, Tsuchida A, Kubota $\mathrm{N}$, et al. Essential role of insulin receptor substrate 1 (IRS-1) and IRS-2 in adipocyte differentiation. Mol Cell Biol 2001; 21: 2521-2532.

50. MacDougald OA, Cornelius $\mathrm{P}$, Lin F-T, Chen SS, Lane MD. Glucocorticoids reciprocally regulate expression of the CCAAT-enhancer-binding protein alpha and delta genes in 3T3-L1 adipocytes and white adipose tissue. J Biol Chem 1994; 269: 19041-19047.

51. Wu Z, Bucher NL, Farmer SR. Induction of peroxisome proliferator-activated receptor gamma during the conversion of $3 \mathrm{~T} 3$ fibroblasts into adipocytes is mediated by C/EBP beta, C/EBP delta, and glucocorticoids. Mol Cell Biol 1996; 16: 4128-4136.
52. Yeh WC, Cao Z, Classon M, McKnight SL. Cascade regulation of terminal adipocyte differentiation by three members of the C/EBP family of leucine zipper proteins. Genes Dev 1995; 9: 168-181.

53. Shin SM, Kim K-Y, Kim JK, Yoon SR, Choi I, Yang Y. Dexamethasone reverses TGF-beta-mediated inhibition of primary rat preadipocyte differentiation. FEBS Lett 2003; 543: 25-30.

54. Cui Q, Wang G-J, Balian G. Steroid-induced adipogenesis in a pluripotential cell line from bone marrow. J Bone Joint Surg Am 1997; 79: 1054-1063.

55. Shi XM, Blair HC, Yang X, McDonald JM, Cao X. Tandem repeat of C/EBP binding sites mediates PPAR gamma2 gene transcription in glucocorticoid-induced adipocyte differentiation. J Cell Biochem 2000; 76: 518-527.

56. Prins JB, Niesler CU, Winterford CM, Bright NA, Siddle K, O'Rahilly $\mathrm{S}$, et al. Tumor necrosis factor-alpha induces apoptosis of human adipose cells. Diabetes 1997; 46: 1939-1944.

57. Ribot J, Oliver P, Serra F, Palou A. Retinoic acid modulates the retinoblastoma protein during adipocyte terminal differentiation. Biochim Biophys Acta 2005; 1740: 249 257.

58. Villarroya F, Giralt M, Iglesias R. Retinoids and adipose tissue: metabolism, cell differentiation and gene expression. Int $\mathrm{J}$ Obes 1999; 23: 1-6.

59. Bost F, Aouadi M, Caron L, Binetruy B. The role of MAPKs in adipocyte differentiation and obesity. Biochimie 2005; 87 : $51-56$.

60. Tang $Q Q$, Otto TC, Lane MD. Mitotic clonal expansion: a synchronous process required for adipogenesis. Proc Natl Acad Sci U S A 2003; 100: 44-49.

61. Camp HS, Tafuri SR. Regulation of peroxisome proliferatoractivated receptor-gamma activity by mitogenactivated protein kinase. J Biol Chem 1997; 272: 10811 10816.

62. Holt EH, Lane MD. Downregulation of repressive CUP/ AP-2 isoforms during adipocyte differentiation. Biochem Biophys Res Commun 2001; 288: 752-756.

63. Tang QQ, Jiang MS, Lane MD. Repressive effect of Sp1 on the C/EBPalpha gene promoter: role in adipocyte differentiation. Mol Cell Biol 1999; 19: 4855-4865.

64. Tang QQ, Lane MD. Role of C/EBP homologous protein (CHOP10 ) in the programmed activation of CCAATenhancerbinding protein-beta during adipogenesis. Proc Natl Acad Sci U S A 2000; 97: 12446-12450.

65. Smas CM, Chen L, Zhao L, Latasa MJ, Sul HS. Transcriptional repression of pref-1 by glucocorticoids promotes 3T3-L1 adipocyte differentiation. J Biol Chem 1999; 274: 12632 12641.

66. Weiss MJ, Orkin SH. GATA transcription factors: key regulators of hematopoiesis. Exp Hematol 1995; 23: 99-107.

67. Tong $\mathrm{Q}$, Dalgin $\mathrm{G}, \mathrm{Xu} \mathrm{H}$, Ting $\mathrm{CN}$, Leiden JM, Hotamisligil GS. Function of GATA transcription factors in preadipocyteadipocyte transition. Science 2000; 290: 134-138.

68. Tong Q, Tsai J, Tan G, Dalgin G, Hotamisligil GS. Interaction between GATA and the C/EBP family of transcription factors is critical in GATA-mediated suppression of adipocyte differentiation. Mol Cell Biol 2005; 25: 706-715.

69. Miller WH Jr, Faust IM, Hirsch J. Demonstration of de novo production of adipocytes in adult rats by biochemical and radioautographic techniques. J Lipid Res 1984; 25 : 3647.

70. Shillabeer G, Lau DC. Regulation of new fat cell formation in rats: the role of dietary fats. J Lipid Res 1994; 35: 592600 . 
71. Ellis RJ, McDonald RB, Stern JS. A diet high in fat stimulates adipocyte proliferation in older (22 month) rats. Exp Gerontol 1990; 25: 141-148.

72. Nakatani T, Kim H-J, Kaburagi Y, Yasuda K, Ezaki O. A low fish oil inhibits SREBP-1 proteolytic cascade, while a highfish-oil feeding decreases SREBP-1 mRNA in mice liver: relationship to anti-obesity. J Lipid Res 2003; 44: 369 379.

73. Okuno M, Kajiwara K, Imai S, Kobayashi T, Honma N, Maki T, et al. Perilla oil prevents the excessive growth of visceral adipose tissue in rats by down-regulating adipocyte differentiation. J Nutr 1997; 127: 1752-1757.

74. Ukropec J, Reseland JE, Gasperikova D, Demcakova E, Madsen L, Berge RK, et al. The hypotriglyceridemic effect of dietary n-3 FA is associated with increased b-oxidation and reduced leptin expression. Lipids 2003; 10: 10231029.

75. Belzung F, Raclot T, Groscolas R. Fish oil n-3 fatty acids selectively limit the hypertrophy of abdominal fat depots in growing rats fed high-fat diets. AmJ Physiol 1993; 264 : R1111R1118.

76. Madsen L, Petersen RK, Kristiansen K. Regulation of adipocyte differentiation and function by polyunsaturated fatty acids Biochim Biophys Acta 2005; 1740: 266-286.

77. Raclot T, Groscolas R, Langin D, Ferre P. Site-specific regulation of gene expression by $n-3$ polyunsaturated fatty acids in rat white adipose tissues. J Lipid Res 1997; 38 . 1963-1972.

78. Ljusberg J, Ek-Rylander B, Anderson G. Tartrate - resistant purple acid phosphatase is synthesized as a latent proenzyme and activated by cysteine proteinases Biochem J 1999; 343 Pt 1: 63 - 69.

79. Angel NZ, Walsh N, Forwood MR, Ostrowski MC, Cassady $\mathrm{Al}$, Hume DA. Transgenic mice overexpressing tartrate - resistant acid phosphatase exhibit an increased rate of bone turnover. J Bone Miner Res 2000; 15: 103 - 110

80. Weisberg SPI McCann D, Desai M, Rosenbaum M, Leibel RL, Ferrante AW Jr. Obesity is associated with macrophage accumulation in adipose tissue. J Clin Invest 2003; 112 . $1796-1808$

81. Xu H, Barnes GT, Yang Q, Tan G, Yang D, Chou CJ, et al. Chronic inflammation in fat plays a crucial role in the development of obesity - related insulin resistance. J Clin Invest 2003; 112: 1821 - 1830 .

82. Bouloumie A, Curat CA, Sengenes C, Lolmede K, Miranville A, Busse R. Role of Macrophage tissue infiltration in metabolic disease. Curr Opin Clin Nutr Metab Care 2005; 8: $347-354$.

83. Lang $\mathrm{P}$, van Harmelen $\mathrm{V}$, Ryden $\mathrm{M}$, Kaaman $\mathrm{M}$, Parini $\mathrm{P}$, Carneheim C, Cassady $\mathrm{Al}$, et al. Monomeric tartrate resistant acid phosphatase induces insulin sensitive obesity. Plos ONE 2008; 3: e1713.

84. Zuk PA, Zhu M, Ashjian P, De Ugarte DA, Huang JI, Mizuno $\mathrm{H}$, et al. Human adipose tissue is a source of multipotent stem cells. Mol Biol Cell 2002; 13: 4279-4295.

85. Nakagami H, Morishita R, Maeda K, Kikuchi $Y$, Ogihara T, Kaneda Y. Adipose tissue-derived stromal cells as a novel option for regenerative cell therapy. J Atheroscler Thromb 2006; 13: 77-78.

86. Dicker A, Le Blanc K, Astrom G, van Harmelen V, Gotherstrom $C$, Blomqvist $L$, et al. Functional studies of mesenchymal stem cells derived from adult human adipose tissue. Exp Cell Res 2005; 308:283-290.

87. Wellen KE, Hotamisligil GS. Obesity-induced inflammatory changes in adipose tissue. J Clin Invest 2003; 112:17851788.
88. Liu L, Meydani M: Angiogenesis inhibitors may regulate adiposity. Nutr Rev 2003; 61:384 -387.

89. Kolonin MG, Saha PK, Chan L, Pasqualini R, Arap W. Reversal of obesity by targeted ablation of adipose tissue. Nat Med 2004; 10:625-632.

90. Rupnick MA, Panigrahy D, Zhang CY, Dallabrida SM, Lowell $\mathrm{BB}$, Langer $\mathrm{R}$, et al. Adipose tissue mass can be regulated through the vasculature. Proc Natl Acad Sci U S A 2002; 99:10730-10735

91. Fukumura D, Ushiyama A, Duda DG, Xu L, Tam J, Krishna V, et al. Paracrine regulation of angiogenesis and adipocyte differentiation during in vivo adipogenesis. Circ Res 2003; 93:e88-e97.

92. McDonald DM, Choyke PL. Imaging of angiogenesis: from microscope to clinic. Nat Med 2003; 9:713-725

93. Rosen ED. The molecular control of adipogenesis, with special reference to lymphatic pathology. Ann N Y Acad Sci 2002; 979:143-158.

94. Krützfeldt J, Stoffel M. MicroRNAs: A new class of regulatory genes affecting metabolism. Cell Metab 2006; 4: 9-12.

95. Bartel DP. MicroRNAs: genomics, biogenesis, mechanism, and function. Cell 2004; 116: 281-297.

96. Selbach M, Schwanhausser B, Thierfelder N, Fang Z, Khanin $\mathrm{R}$, Rajewsky N. Widespread changes in protein synthesis induced by microRNAs. Nature 2008; 455: 58-63.

97. Baek D, Villen J, Shin C, Camargo FD, Gygi SP, Bartel DP. The impact of microRNAs on protein output. Nature 2008; 455: $64-71$

98. Xie H, Lim B, Lodish HF. MicroRNAs induced during adipogenesis that accelerate fat cell development are downregulated in obesity. Diabetes 2009; 58: 1050 1057

99. Charles AC, Naus CC, Zhu D, Kidder GM, Dirksen ER, Sanderson MJ. Intercellular calcium signaling via gap junctions in glioma cells. J Cell Biol 1992; 118: 195-120.

100. Kam Y, Kim DY, Koo SK, Joe CO. Transfer of second messengers through gap junction connexin 43 channels reconstituted in liposomes. Biochim Biophys Acta 1998; 1372: $384-388$

101. Schmalbruch $H$. Skeletal muscle fibers of newborn rats are coupled by gap junctions. Dev Biol 1982; 91: 485-490.

102. Balogh S, Naus CC, Merrifield PA. Expression of gap junctions in cultured rat L6 cells during myogenesis. Dev Biol 1993; 155: $351-360$

103. Proulx A. Merrifield PA, Naus CC. Blocking gap junctional intercellular communication in myoblasts inhibits myogenin and MRF4 expression. Dev Genet 1997; 20: 133- 144.

104. Lecanda F, Towler DA, Ziambaras K, Cheng SL, Koval M, Steinberg TH, et al. Gap junctional communication modulates gene expression in osteoblastic cells. Mol Biol Cell 1998; 9: $2249-2258$.

105. Lecanda F, Warlow PM, Sheikh S, Furlan F, Steinberg TH, Civitelli R. Connexin43 deficiency causes delayed ossification, craniofacial abnormalities, and osteoblast dysfunction. J Cell Biol 2000; 151: 931-943.

106. Schiller PC, D'Ippolito G, Balkan W, Roos BA, Howard GA. Gap-junctional communication is required for the maturation process of osteoblastic cells in culture. Bone 2001; 28: 362-369.

107. Schiller PC, D'Ippolito G, Balkan W, Roos BA, Howard GA. Gap-junctional communication mediates parathyroid hormone stimulation of mineralization in osteoblastic cultures. Bone 2001; 28: 38-44 
108. Saez JC, Berthoud VM, Branes MC, Martinez AD, Beyer EC. Plasma membrane channels formed by connexins: their regulation and functions. Physiol Rev 2003; 83: 1359400.

109. Umezawa A, Hata J. Expression of gap-junctional protein (connexin 43 or a1 gap junction) is down-regulated at the transcriptional level during adipocyte differentiation of H-1/A marrow stromal cells. Cell Struct Funct 1992; 17 : $177-184$

110. Yanagiya T, Tanabe A. Hotta K. Gap-jucntional communication is required formitotic clonal expansion during adipogenesis Obesity 2007; 15: $572-582$.

111. Lazar MA. How now, brown fat? Science 2008; 321: 1048 1049.

112. Timmons JA, Wennmalm K, Larsson O, Walden TB, Lassmann $\mathrm{T}$, Petrovic N, et al. Myogenic gene expression signature establishes that brown and white adipocytes originate from distinct cell lineages. Proc Natl Acad Sci USA 2007: 104: 4401 - 4406 .

113. Cannon B, Nedergaard J. Neither fat nor flesh. Nature 2008; 454: $947-948$

114. Rothwell NJ, Stock MJ. Diet-induced thermogenesis. Adv Nutr Res 1983; 5: 201-220

115. Bouchard C, Tremblay A, Despres JP, Nadeau A, Lupien PJ, Theriault $\mathrm{G}$, et al. The response to long-term overfeeding in identical twins. N Engl J Med 1990; 322: 1477-1482.

116. Leibel RL. Molecular physiology of weight regulation in mice and humans. Int J Obes (Lond) 2008; 32(Suppl. 7): S98S108.

117. Wijers SL, Saris WH, van Marken Lichtenbelt WD. Recent advances in adaptive thermogenesis: potential implications for the treatment of obesity. Obes Rev 2009; 10: 218-226.

118. Seale P, Bjork B, Yang W, Kajimura S, Chin S, Kuang S, et al. PRDM16 controls a brown fat/skeletal muscle switch. Nature 2008; 454: 961-967.

119. Seale P, Kajimura S, Yang W, Chin S, Rohas LM, Uldry M, et al. Transcriptional control of brown fat determination by PRDM16. Cell Metab 2007; 6: 38-54.

120. Tseng YH, Kokkotou E, Schulz TJ, Huang TL, Winnay JN, Taniguchi CM, et al. New role of bone morphogenetic protein 7 in brown adipogenesis and energy expenditure. Nature 2008; 454: 1000-1004.

121. Seale P. Lazar MA. Brown fat in humans: turning up the heat on obesity. Diabetes 2009; 58: $1482-1484$.

122. Rosen ED. The transcriptional basis of adipocyte development Prostaglandins Leukot Essent Fatty Acids 2005; 73: 31 34

123. Choy L, Skillington J, Derynck R. Roles of autocrine TGF-b receptor and Smad signaling in adipocyte differentiation. J Cell Biol 2000; 149: 667-682.

124. Choy L, Derynck R. Transforming growth factor-b inhibits adipocyte differentiation by Smad3 interacting with CCAAT/enhancer-binding protein (C/EBP) and repressing C/EBP transactivation function. J Biol Chem 2003; 278 : 9609-9619

125. Sparks RL, Allen BJ, Zygmunt Al, Strauss EE. Loss of differentiation control in transformed 3T3 T proadipocytes. Cancer Res 1993; 53: 1770-1776.

126. Samad F, Yamamoto K, Pandey M, Loskutoff DJ. Elevated expression of transforming growth factor-beta in adipose tissue from obese mice. Mol Med 1997; 3: 37-48.

127. Horie T, Ono K, Kinoshita M, Nishi H, Nagao K, Kawamura T, et al. TG - interacting factor is required for the differentiation of preadipocytes. J Lipid Res 2008; 49: 1224 - 1234.

128. Pi-Sunyer FX. Obesity: determinants and therapeutic initiatives. Nutrition 1991; 7: 292-294.
129. Krieger-Brauer $\mathrm{HI}$, Kather $\mathrm{H}$. Human fat cells possess a plasma membrane-bound $\mathrm{H} 2 \mathrm{O} 2$-generating system that is activated by insulin via a mechanism bypassing the receptor kinase. J Clin Invest 1992; 89: 1006-1013.

130. Bedard $\mathrm{K}$, Krause $\mathrm{KH}$. The NOX family of ROS-generating NADPH oxidases: physiology and pathophysiology Physiol Rev 2007; 87: 245-313

131. Ambasta RK, Kumar $P$, Griendling KK, Schmidt $H H$, Busse R, Brandes RP. Direct interaction of the novel Nox proteins with $\mathrm{p} 22 \mathrm{phox}$ is required for the formation of a functionally active NADPH oxidase. J Biol Chem 2004; 279: 4593545941.

132. Sturrock A, Huecksteadt TP, Norman K, Sanders K, Murphy TM, Chitano P, et al. Nox4 mediates TGFbeta1-induced retinoblastoma protein phosphorylation, proliferation, and hypertrophy in human airway smooth muscle cells. Am J Physiol Lung Cell Mol Physio. 2007; 292: L1543-L1555.

133. Schröder K, Wandzioch K, Helmcke I, Brandes RP. Nox4 acts as a switch between differentiation and proliferation in preadipocytes. Arterioscler Thromb Vasc Biol 2009; 29 . $239-245$

134. Esau C, Kang X, Peralta E, Hanson E, Marcusson EG, Ravichandran LV, et al. MicroRBA - 143 regulates adipocyte differentiation. J Biol Chem 2004; 279: 52361 52365

135. Sul HS, Smas C, Mei N, Zhou L. Function of pref-1 as an inhibitor of adipocyte differentiation. Int J Obes 2000; 24 (suppl.4): S15 - S19.

136. Smas CM, Sul HS. Pref-1, a protein containing EGF-like repeats, inhibits adipocyte differentiation. Cell 1993; 73 . $725-734$.

137. Smas CM, Sul HS. Molecular mechanisms of adipocyte differentiation and inhibitory action of pref-1. Crit Rev Eukaryotic Gene Expression 1997; 7: 281 - 298.

138. Sul HS, Smas CM, Mei B, Zhou L. Regulation of fat synthesis and adipose differentiation. Prog Nucleic Acid Res Mol Biol 1997; 60: 317 - 345 .

139. Smas CM, Kachinskas D, Liu CM, Xie X, Dircks LK, Sul HS. Transcriptional control of the pref-1 gene in 3T3L1 adipocyte differentiation. Sequence requirement for differentiation-dependent suppression. J Biol Chem 1998; 273: 31751-31758

140. Shimomura I, Hammer RE, Richardson JA, Ikemoto S, Bashmakov $Y$, Goldstein JL, et al. Insulin resistance and diabetes mellitus in transgenic mice expressing nuclear SREBP-1c in adipose tissue: model for congenital generalized lipodystrophy. Genes Dev 1998; 12: 31823194

141. Tseng YH, Butte AJ, Kokkotou E, Yechoor VK, Taniguchi $\mathrm{CM}$, Kriauciunas KM, et al. Prediction of preadipocyte differentiation by gene expression reveals role of insulin receptor substrates and necdin. Nat Cell Biol 2005; 7 : 601-611.

142. Zhou YT, Wang ZW, Higa M, Newgard CB, Unger CB. Reversing adipocyte differentiation: implications for treatment of obesity. Proc Natl Acad Sci USA 1999; 96: 2391-2395.

143. Kim KA, Kim JH, Wang Y, Sul HS. Pref-1 (Preadipocyte factor - 1) activates the MEK/extracellular signal - regulated kinase pathway to inhibit adipocyte differentiation. Mol Cell Biol 2007; $27: 2294-2308$

144. Cho KJ, Moon HE, Moini H, Packer L, Yoon DY, Chung AS. A-Lipoic acid inhibits adipocyte differentiation by regulating pro-adipogenic transcription factors via mitogen - activated protein kinase pathways. J Biol Chem 2003; 278: $34823-34833$ 
145. Isakson P, Hammarstedt A, Gustafson B, Smith U. Impaired preadipocyte differentiation in human abdominal obesity. Role of wnt, tumor necrosis factor $-\alpha$, and inflammation. Diabetes 2009; 58: 1550 - 1557.

146. Bouloumie A, Lolmede K, Sengenes C, Galitzky J, Lafontan M. Angiogenesis in adipose tissue. Ann Endocrinol. (Paris) 2002; 63: 91-95.

147. Crandall DL, Hausman GJ, Kral JG. A review of the microcirculation of adipose tissue: anatomic, metabolic, and angiogenic perspectives. Microcirculation 1997; 4: 211-232.

148. Silverman KJ, Lund DP, Zetter BR, Lainey LL, Shahood JA, Freiman DG, et al. Angiogenic activity of adipose tissue. Biochem Biophys Res Commun 1988; 153: 347-352.

149. Hausman GJ, Richardson RL. Adipose tissue angiogenesis. J Anim Sci 2004; 82: 95 - 934.

150. Baillargeon J, Rose DP. Obesity, adipokines, and prostate cancer (review). Int J Oncol 2006; 28: 737-745.55.

151. Friedman JM, Halaas $\mathrm{JL}$. Leptin and the regulation of body weight in mammals. Nature 1998; 395: 763-770.

152. Hiraoka $Y$, Yamashiro $H$, Yasuda $K$, Kimura $Y$, Inamoto $T$, Tabata $\mathrm{Y}$. In situ regeneration of adipose tissue in rat fat pad by combining a collagen scaffold with gelatin microspheres containing basic fibroblast growth factor. Tissue Eng 2006; 12: 1475-1487.

153. Kuo LE, Zukowska Z. Stress, NPY and vascular remodeling: Implications for stress-related diseases. Peptides 2007; 28: 435-440.

154. Lijnen HR, Christiaens V, Scroyen I, Voros G, Tjwa M, Carmeliet $\mathrm{P}$, et al. Impaired adipose tissue development in mice with inactivation of placental growth factor function. Diabetes 2006; 55: 2698-2704.

155. Mu H, Ohashi R, Yan S, Chai H, Yang H, Lin $\mathrm{P}$, et al. Adipokine resistin promotes in vitro angiogenesis of human endothelial cells. Cardiovas. Res 2006; 70: 146-157.

156. Saiki A, Watanabe $F$, Murano $T$, Miyashita $Y$, Shirai $K$. Hepatocyte growth factor secreted by cultured adipocytes promotes tube formation of vascular endothelial cells in vitro. Int J Obes (Lond) 2006; 30: 1676-1684.

157. Samad F, Pandey M, Loskutoff DJ. Tissue factor gene expression in the adipose tissues of obese mice. Proc Natl Acad Sci USA 1998; 95: 7591-7596.

158. Voros G, Maquoi E, Demeulemeester D, Clerx N, Collen D, Lijnen HR. Modulation of angiogenesis during adipose tissue development in murine models of obesity. Endocrinology 2005; 146: 4545-4554.

159. Dobson DE, Kambe A, Block E, Dion T, Lu H, Castellot JJ Jr, et al. 1-Butyryl-glycerol: a novel angiogenesis factor secreted by differentiating adipocytes. Cell 1990; 61: 223-230.

160. Wilkison WO, Choy L, Spiegelman BM. Biosynthetic regulation of monobutyrin, an adipocyte-secreted lipid with angiogenic activity. J Biol Chem 1991; 266: 16886-16891.

161. Bouloumie A, Sengenes C, Portolan G, Galitzky J, Lafontan M. Adipocyte produces matrix metalloproteinases 2 and 9: involvement in adipose differentiation. Diabetes 2001; 50: 2080-2086.

162. Wellen KE, Hotamisligil GS. Inflammation, stress, and diabetes. J Clin Invest 2005; 115: 1111-1119.

163. Cao Y. Angiogenesis modulates adipogenesis and obesity. $\mathrm{J}$ Clin Invest 2007; 117: 2362 - 2368.

164. Dallabrida SM, Zurakowski D, Shih SC, Smith LE, Folkman J, Moulton KS, et al. Adipose tissue growth and regression are regulated by angiopoietin-1. Biochem Biophys Res Commun 2003; 311: 563-571.
165. Murphy DJ, Vance J. Mechanisms of lipid-bodu formation Trends Biochem 1999; 24: 109 - 115.

166. Jiang HP, Serrero G. Isolation and characterization of a fulllength cDNA coding for an adipose differentiation-related protein. Proc Natl Acad Sci USA. 1992 ; 89: 7856-7860.

167. Marchesan D, Rutberg M, Andersson L, e Asp L, Larsson T, Borén $\mathrm{J}$, et al. A phospholipase D-dependent process forms lipid droplets containing caveolin, adipocyte differentiationrelated protein, and vimentin in a cell-free system. J Biol Chem 2003; 278: 27293-27300

168. Andersson L, Boström P, Ericson J, Rutberg M, Magnusson $B$, Marchesan D, et al. PLD1 and ERK2 regulate cytosolic lipid droplet formation. J Cell Sci 2006; 119:2246-2257.

169. Gonzalez-Baro MR, Lewin TM, Coleman RA. Regulation of triglyceride metabolism. II. Function of mitochondrial GPAT1 in the regulation of triacylglycerol biosynthesis and insulin action. Am J Physiol Gastrointest Liver Physiol 2007; 292:G1195-G1199.

170. Coleman RA, Lewin TM, Muoio DM. Physiological and nutritional regulation of enzymes of triacylglycerol synthesis. Annu Rev Nutr 2000; 20:77-103.

171. Carman GM, Han GS. Roles of phosphatidate phosphatase enzymes in lipid metabolism. Trends Biochem Sci 2006; 31:694-699.

172. Stone SJ, Levin MC, Farese RV Jr. Membrane topology and identification of key functional amino acid residues of murine acyl-CoA:diacylglycerol acyltransferase-2. J Biol Chem 2006; 281:40273-40282.

173. Turkish A, Sturley SL. Regulation of triglyceride metabolism. I. Eukaryotic neutral lipid synthesis: "many ways to skin ACAT or a DGAT'. Am J Physiol Gastrointest Liver Physiol 2007; 292:G953-G957.

174. Welte MA, Gross SP, Postner M, Block SM, Wieschaus EF Developmental regulation of vesicle transport in Drosophila embryos: forces and kinetics. Cell 1998; 92:547-557.

175. Boström P, Rutberg M, Ericsson J, Holmdahl P, Andersson L, Frohman MA, et al. Cytosolic lipid droplets increase in size by microtubule-dependent complex formation. Arterioscler Thromb Vasc Biol 2005; 25:1945-1951.

176. Hong W. SNAREs and traffic. Biochim Biophys Acta 2005 1744:493-517.

177. Jahn R, Scheller RH. SNAREs: engines for membrane fusion Nat Rev Mol Cell Biol 2006; 7:631-643.

178. Olofsson SO, Boström P, Andersson L, Rutberg M, Levin M Perman J, et al. Triglyceride containing lipid droplets and lipid droplet-associated proteins. Curr Opin Lipidol. 2008; 19: 441-447.

179. Boström $\mathrm{P}$, Andersson L, Rutberg M, Perman J, Lidberg U, Johansson BR, et al. SNARE proteins mediate fusion between cytosolic lipid droplets and are implicated in insulin sensitivity. Nat Cell Biol 2007; 9:1286-1293.

180. Machann J, Haring $H$, Schick F, Stumvoll M. Intramyocellular lipids and insulin resistance. Diabetes Obes Metab 2004 6:239-248.

181. Falholt $\mathrm{K}$, Jensen I, Lindkaer Jensen S, Mortensen $\mathrm{H}$, Vølund A, et al. Carbohydrate and lipid metabolism of skeletal muscle in type 2 diabetic patients. Diabet Med 1988; 5:27-31.

182. Krssak M, Falk Petersen K, Dresner A, DiPietro L, Vogel SM, Rothman DL, et al. Intramyocellular lipid concentrations are correlated with insulin sensitivity in humans: a 1H NMR spectroscopy study. Diabetologia 1999; 42:113-116.

183. Yki-Jarvinen $\mathrm{H}$. Ectopic fat accumulation: an important cause of insulin resistance in humans. J R Soc Med 2002; 95 (Suppl 42):39-45. 
184. Yu YH, Ginsberg HN. Adipocyte signaling and lipid homeostasis: sequelae of insulin-resistant adipose tissue. Circ Res 2005; 96:1042-1052.

185. Kovacs $P$, Stumvoll $M$. Fatty acids and insulin resistance in muscle and liver. Best Pract Res Clin Endocrinol Metab 2005; 19:625-635

186. Sell H, Dietze-Schroeder D, Eckel J. The adipocyte-myocyte axis in insulin resistance. Trends Endocrinol Metab 2006 $17: 416-422$.

187. Goossens GH. The role of adipose tissue dysfunction in the pathogenesis of obesity-related insulin resistance. Physiol Behav 2008; 94:206-218

188. Savage DB, Petersen KF, Shulman GI. Disordered lipid metabolism and the pathogenesis of insulin resistance. Physiol Rev 2007; 87:507-520.

189. Morino K, Petersen KF, Shulman GI. Molecular mechanisms of insulin resistance in humans and their potential links with mitochondrial dysfunction. Diabetes 2006; 55 (Suppl 2):S9-S15

190. Summers SA. Ceramides in insulin resistance and lipotoxicity. Prog Lipid Res 2006; 45:42-72.

191. Koves TR, Ussher JR, Noland RC, Slentz D, Mosedale M, Ilkayeva O RC, et al. Mitochondrial overload and incomplete fatty acid oxidation contribute to skeletal muscle insulin resistance. Cell Metab 2008; 7:45-56.

192. Martin S, Parton RG. Lipid droplets: a unified view of a dynamic organelle. Nat Rev Mol Cell Biol 2006; 7:373-378.

193. Ozeki S, Cheng J, Tauchi-Sato K, Hatano N, Taniguchi $\mathrm{H}$, Fujimoto $\mathrm{T}$, et al. Rab18 localizes to lipid droplets and induces their close apposition to the endoplasmic reticulum-derived membrane. J Cell Sci 2005; 118: 2601 2611.

194. Binns D, Januszewski T, Chen Y, Hill J, Markin VS, Zhao $Y$, et al. An intimate collaboration between peroxisomes and lipid bodies. J Cell Biol 2006; 173:719-731.

195. Liu P, Bartz R, Zehmer JK, Ying YS, Zhu M, Serrero G, et al. Rab-regulated interaction of early endosomes with lipid droplets. Biochim Biophys Acta 2007; 1773:784-793.

196. Shaw CS, Jones DA, Wagenmakers AJ. Network distribution of mitochondria and lipid droplets in human muscle fibres. Histochem Cell Biol 2008; 129:65-72.

197. Puri V, Czech MP. Lipid droplets: FSP27 knockout enhances their sizzle. J Clin Invest 2008; 118: 2693 - 2696.

198. Nishino N, Tamori $Y$, Tateya $S$, Kawaguchi $T$, Shibakusa $T$, Mizunoya W, et al. FSP27 contributes to efficient energy storage in murine white adipocytes by promoting the formation of unilocular lipid droplets. J Cli. Invest 2008; 118: 2808-2821.

199. Ducharme NA, Bickel PE. Minireview: Lipid droplets in lipogenesis and lipolysis. Endocrinology 2008; 149: 942 929.

200. Londos C, Brasaemle DL, Schultz CJ, Segrest JP, Kimmel AR Perilipins, ADRP, and other proteins that associate with intracellular neutral lipid droplets in animal cells. Semin Cell Dev Biol 1999; 10:51-58.

201. Dalen KT, Dahl T, Holter E, Arntsen B, Londos C, Sztalryd C, et al. LSDP5 is a PAT protein specifically expressed in fatty acid oxidizing tissues. Biochim Biophys Acta 2007; 1771:210-227.

202. Brasaemle DL. Thematic review series: adipocyte biology The perilipin family of structural lipid droplet proteins: stabilization of lipid droplets and control of lipolysis. J Lipid Res 2007; 48:2547-2559.

203. Wolins NE, Quaynor BK, Skinner JR, Tzekov A, Croce MA, Gropler MC, et al. OXPAT/PAT-1 is a PPAR-induced lipid droplet protein that promotes fatty acid utilization. Diabetes 2006; 55: 3418-3428.
204. Yamaguchi T, Matsushita S, Motojima K, Hirose F, Osumi $T$. MLDP, a novel PAT family protein localized to lipid droplets and enriched in the heart, is regulated by peroxisome proliferatoractivated receptor alpha. J Biol Chem 2006; 281: 14232-14240.

205. Greenberg AS, Ega JJ, Wek SA, Moos, Jr MC, Londos C, Kimmel AR, et al AR. The murine perilipin gene: the lipid droplet-associated perilipins derive from tissue-specific, mRNA splice variants and define a gene family of ancient origin. Mamm. Genome 2001; 12: 741-749.

206. Greenberg AS, Egan JJ, Wek SA, Garty NB, BlanchetteMackie EJ, Londos C. Perilipin, a major hormonally regulated adipocyte-specific phosphoprotein associated with the periphery of lipid storage droplets. J Biol Chem 1991; 266: 1341-11346.

207. Servetnick DA, Brasaemle DL, Gruia-Gray J, Kimmel AR, Wolff $\mathrm{J}$, Londos C. Perilipins are associated with cholesteryl ester droplets in steroidogenic adrenal cortical and Leydig cells. J Biol Chem 1995; 270: 16970-16973

208. Souza SC, Muliro KV, Liscum L, Lien P, Yamamoto MT, Schaffer JE, et al. Modulation of hormone-sensitive lipase and protein kinase A-mediated lipolysis by perilipin A in an adenoviral reconstituted system. J Biol Chem 2002; 277 : 8267-8272.

209. Tansey JT, Hum AM, Vogt R, Davis KE, Jones JM, Fraser $K A$, Functional studies on native and mutated forms of perilipins. A role in protein kinase A-mediated lipolysis of triacylglycerols. J Biol Chem 2003; 278: 8401-8406.

210. Subramanian V, Rothenberg A, Gomez C, Cohen AW, Garcia A, Bhattacharyya S, et al. Perilipin A mediates the reversible binding of CGI-58 to lipid droplets in 3T3-L1 adipocytes. J Biol Chem 2004; 279: 42062-42071.

211. Yamaguci $\mathrm{T}$, Omatsu $\mathrm{N}$, Matsushita $\mathrm{S}$, Osumi T. CGI-58 interacts with perilipin and is localized to lipid droplets: possible involvement of CGI-58 mislocalization in Chanarin-Dorfman syndrome. J Biol Chem 2004; 279 . 30490-30497.

212. Lass A, Zimmermann R, Haemmerle G, Riederer $M$, Schoiswohl G, Schweiger M, et al. Adipose triglyceride lipasemediated lipolysis of cellular fat stores is activated by CGI-58 and defective in Chanarin-Dorfman syndrome. Cell Metab 2006; 3: 309-319.

213. Schweiger M, Schreibe R, G. Haemmerle, A. Lass, C. Fledelius, $\mathrm{P}$. Jacobsen, Tornqvist H, Zechner R, Zimmermann R. Adipose triglyceride lipase and hormone-sensitive lipase are the major enzymes in adipose tissue triacylglycerol catabolism. J Biol Chem 2006; 281: 40236-40241.

214. Arimura $N$, Horiba $T$, Imagawa $M$, Shimizu M, Sato $R$. The peroxisome proliferator - activated receptor y regulates expression of the perilipin gene in adipocytes. J Blio Chem 2004; 279: $10070-10076$

215. Qi L, Corella D, Sorli JV, Portolés O, Shen H, Coltell O, Godoy $D$, et al. Genetic variation at the perilipin (PLIN) locus is associated with obesity-related phenotypes in White women. Clin Genet 2004; 66: 299-310

216. Qi L, Shen H, Larson I, Schaefer EJ, Greenberg AS, Tregouet DA, et al. Gender-specific association of a perilipin gene haplotype with obesity risk in a white population. Obes Res 2004; 12: 1758-1765.

217. Qi L, Tai ES, Tan CE, Shen H, Chew SK, Greenberg AS, et al. Intragenic linkage disequilibrium structure of the human perilipin gene (PLIN) and haplotype association with increased obesity risk in a multiethnic Asian population. $J$ Mol Med 2005; 83: 448-456

218. Corella D, Qi L, Tai ES, Deurenberg-Yap M, Tan CE, Chew SK, et al. Perilipin gene variation determines higher susceptibility to insulin resistance in Asian women when consuming a highsaturated fat, low-carbohydrate diet Diabetes Care 2006; 29: 1313-1319. 
219. Tai ES, Ordovas JM. The role of perilipin in human obesity and insulin resistance. Curr Opin Lipidol 2007; 18: 152 - 156.

220. Souza SC, Christoffolete MA, Ribeiro MO, Miyoshi $H$, Strissel KJ, Stancheva ZS, et al. Perilipin regulates the thermogenic actions of norepinephrine in brown adipose tissue. J Lipid Res 2007; 48: 1273 - 1279.

221. Mottagul - Tabar S, Rydén M, Löfgren P, Faulds G, Hoffstedt $\mathrm{J}$, Brookes AJ, et al. Evidence for an important role of perilipin in the regulation of human adipocyte lipolysis. Diabetologia 2003; 46: 789 - 797 .

222. Londos C, Sztalryd C, Tansey JT, Kimmel AR. Role of PAT proteins in lipid metabolism. Biochimie 2005; 87: $45-49$.

223. Arner P. Human fat cell lipolysis: biochemistry, regulation and clinical role. Best Pract Res Clin Endocrinol Metab 2005; 19: $471-482$.

224. Schaffer J. E. Lipotoxicity: when tissues overeat. Curr Opin Lipidol 2003; 14: 281-287.

225. Unger R H. Lipotoxic diseases. Annu Rev Med 2002; 53: 319 336.

226. Zechner R, Kienesberger PC, Haemmerie G, Zimmermann $\mathrm{R}$, Lass A. Adipose triglyceride lipase and the lipolytic catabolism of cellular fat stores. J Lipid Res 2009; 50: 3 21.

227. Langin D. Adipose tissue lipolysis as a metabolic pathway to define pharmacological strategies against obesity and the metabolic syndrome. Pharmacol Res 2006; 53: 482-491.

228. Holm C, Osterlund T, Laurell H, Contreras JA. Molecular mechanisms regulating hormone-sensitive lipase and lipolysis. Annu Rev Nut 2000;. 20: 365-393.

229. Lafontan $M$, Berlan $M$. Fat cell adrenergic receptors and the control of white and brown fat cell function. J Lipid Res 1993; 34: 1057-1091.

230. Collins S, Cao W, Robidoux J. Learning new tricks from old dogs: beta-adrenergic receptors teach new lessons on firing up adipose tissue metabolism. Mol Endocrinol 2004; 18: 2123-2131.

231. Holm C. Molecular mechanisms regulating hormonesensitive lipase and lipolysis. Biochem Soc Trans 2003; 31: 11201124.

232. Larrouy D., Galitzky J, Lafonta Mn. A1 adenosine receptors in the human fat cell: tissue distribution and regulation of radioligand binding. Eur $\mathrm{J}$ Pharmacol 1991; 206: 139147.

233. Richelsen B.. Release and effects of prostaglandins in adipose $\square$ tissue. Prostaglandins Leukot Essent Fatty Acids. 1992; 47: 171-182.

234. Bradley RL, Mansfield JP, Maratos-Flier E. Neuropeptides, including neuropeptide $\mathrm{Y}$ and melanocortins, mediate $\square$ lipolysis in murine adipocytes. Obes Res 2005; 13: $653-661$.

235. Offermanns S. The nicotinic acid receptor GPR109A(HM74A or PUMA-G) as a new therapeutic target. Trends Pharmacol Sci 2006; 27: 384-390.

236. Degerman E, Landstrom TR, Wijkander J, Holst LS, Ahmad $F$, Belfrage $P$, et al. Phosphorylation and activation of hormone-sensitive adipocyte phosphodiesterase type 3B. Methods 1998; 14: 43-53.

237. Taniguchi CM, Emanuelli B, Kahn CR. Critical nodes in signalling pathways: insight into insulin action. Mat Rev Mol Cell Biol 2006; 7: 85-96.

238. Yeaman SJ. Hormone-sensitive lipase - a multipurpose enzyme in lipid metabolism. Biochim Biophys Acta. 1990; 1052: 128-132.

239. Zimmermann R, Strauss JG, Haemmerle G, Schoiswohl G, Birner-Gruenberger $\mathrm{R}$, Riederer $\mathrm{M}$, et al. Fat mobilization in adipose tissue is promoted by adipose triglyceride lipase. Science 2004; 306: 1383-1386.
240. Villena JA, Roy S, Sarkadi-Nagy S, Kim KH, Sul HS. Desnutrin, an adipocyte gene encoding a novel patatin domain-containing protein, is induced by fasting and glucocorticoids: ectopic expression of desnutrin increases triglyceride hydrolysis. J Biol Chem 2004; 279: 4706647075 .

241. Jenkins CM., Mancuso DJ, Yan W, Sims HF, Gibson B, Gross RW. Identification, cloning, expression, and purification of three novel human calcium-independent phospholipase A2 family members possessing triacylglycerol lipase and acylglycerol transacylase activities. J Biol Chem 2004; 279: 48968-48975.

242. Wilson PA, Gardner SD, Lambie NM, Commans SA Crowther DJ. Characterization of the human patatin-like phospholipase family. J Lipid Res 2006; 47: 1940-1949.

243. Zechner R, Strauss JG, Haemmerle G, Lass A, Zimmermann R. Lipolysis: pathway under construction. Curr Opin Lipidol 2005; 16: 333-340.

244. Notari L, Baladron V, Aroca-Aguilar VD, Balko N, Heredia $\mathrm{R}$, Meyer $\mathrm{C}$, et al. Identification of a lipase-linked cell membrane receptor for pigment epithelium-derived factor J Biol Chem 2006; 281: 38022-38037.

245. Lefevre C, Jobard F, Caux F, Bouadjar B, Karaduman A, Heilig $\mathrm{R}$, et al. Mutations in CGI-58, the gene encoding a new protein of the esterase/lipase/thioesterase subfamily, in Chanarin-Dorfman syndrome. Am J Hum Genet 2001; 69 : 1002-1012.

246. Miyoshi H, Perfield II JW, Souza SC, Shen WJ, Zhang HH, Stancheva ZS, et al. Control of adipose triglyceride lipase action by serine 517 of perilipin A globally regulates protein kinase A-stimulated lipolysis in adipocytes. $\mathrm{J}$ Biol Chem 2007; 282: 996-1002

247. Inohara N, Koseki T, Chen S, Wu X, Nunez G. CIDE, a novel family of cell death activators with homology to the $45 \mathrm{kDa}$ subunit of the DNA fragmentation factor. EMBO J 1998; 17: $2526-2533$

248. Puri V, Konda S, Ranjit S, Aouadi M, Chawla A, Chouinard M, et al. Fat-specific protein 27, a novel lipid droplet protein that enhances triglyceride storage. J Biol Chem 2007; 282: 34213-34218.

249. Puri V, Ranjit S, Konda S, Nicoloro SM, Straubhaar J, Chawla A, et al. Cidea is associated with lipid droplets and insulin sensitivity in humans. Proc Natl Acad Sci USA. 2008; 105 : 7833-7838.

250. Toh SY, Gong J, Du G, Li JZ, Yang S, Ye J, et al. Up-regulation of mitochondrial activity and acquirement of brown adipose tissue-like property in the white adipose tissue of fsp27 deficient mice. PLOS ONE. 2008; 3: e2890.

251. Nawrocki AR, Scherer PE. Keynote review: the adipocyte as a drug discovery target. Drug Discov Today 2005; 10:1219 -1230 .

252. Cook KS, Min HY, Johnson D, Chaplinsky RJ, Flier JS, Hunt $\mathrm{CR}$, et al. Adipsin: a circulating serine protease homolog secreted by adipose tissue and sciatic nerve. Science 1987; 237:402- 405

253. Zhang Y, Proenca R, Maffel M, Barone M, Leopold L, Friedman JM. Positional cloning of the mouse obese gene and its human homologue. Nature 1994; 372:425- 432.

254. Scherer PE, Williams S, Fogliano M, Baldini G, Lodish HF. A novel serum protein similar to $\mathrm{C} 1 \mathrm{q}$, produced exclusively in adipocytes. J Biol Chem 1995; 270:26746 -26749.

255. Hu E, Liang P, Spiegelman BM. AdipoQ is a novel adiposespecific gene dysregulated in obesity. J Biol Chem 1996; 271:10697-10703.

256. Maeda K, Okubo K, Shimomura I, Funahashi T, Matsuzawa $\mathrm{Y}$, Matsubara K. cDNA cloning and expression of a novel adipose specific collagen-like factor, apM1 (AdiPose Most abundant Gene transcript 1). Biochem Biophys Res Commun 1996; 221:286-289. 
257. Nakano Y, Tobe T, Choi-Miura NH, Mazda T, Tomita M: Isolation and characterization of GBP28, a novel gelatin-binding protein purified from human plasma. J Biochem (Tokyo) 1996; 120:803- 812.

258. Steppan CM, Bailey ST, Bhat S, Brown EJ, Banerjee RR, Wright $\mathrm{CM}$, et al. The hormone resistin links obesity to diabetes. Nature 2001; 409:307-312.

259. Rajala MW, Lin Y, Ranalletta M, Yang XM, Qian H, Gingerich $\mathrm{R}$, et al. Cell type-specific expression and coregulation of murine resistin and resistin-like molecule-alpha in adipose tissue. Mol Endocrinol 2002; 16:1920 -1930.

260. Cianflone K, Maslowska M, Sniderman AD: Acylation stimulating protein (ASP), an adipocyte autocrine: new directions. Semin Cell Dev Biol 1999; 10:31-41.

261. Fukuhara A, Matsuda M, Nishizawa M, Segawa K, Tanaka M, Kishimoto $\mathrm{K}$, et al. Visfatin: a protein secreted by visceral fat that mimics the effects of insulin. Science 2005; $307: 426-430$

262. Arner P: Visfatin: a true or false trail to type 2 diabetes mellitus. J Clin Endocrinol Metab 2006; 91:28 -30.

263. Yang Q, Graham TE, Mody N, Preitner F, Peroni OD, Zabolotny $\mathrm{JM}$, et al. Serum retinol binding protein 4 contributes to insulin resistance in obesity and type 2 diabetes. Nature 2005; 436:356-362.

264. Lin Y, Rajala MW, Berger JP, Moller DE, Barzilai N, Scherer PE. Hyperglycemia-induced production of acute phase reactants in adipose tissue. J Biol Chem 2001; 276:4207742083

265. Scherer PE. Adipose tissue. From lipid storage compartment to endocrine organ. Diabetes 2006; 55: 1537 - 1545.

266. Ahima RS, Flier JS. Adipose tissue as an endocrine organ. Trends Endocrinol Metab 2000; 11:327-332.

267. Fruhbeck G, Gomez-Ambrosi J, Muruzabal FJ, Burrell MA The adipocyte: a model for integration of endocrine and metabolic signaling in energy metabolism regulation. Am J Physiol Endocrinol Metab 2001; 280:E827-E847.

268. Fain JN, Madan AK, Hiler ML, Cheema P, Bahouth SW. Comparison of the release of adipokines by adipose tissue, adipose tissue matrix, and adipocytes from visceral and subcutaneous abdominal adipose tissues of obese humans. Endocrinology 2004; 145:2273-2282

269. Kershaw EE, Flier JS. Adipose tissue as an endocrine organ. J Clin Endocrinol Metab 2004; 89: 2548 - 2556.

270. Ronti T, Lupattelli G, Mannarino $\mathrm{E}$. The endocrine function of adipose tissue: an update. Clin Endocrinol 2006; 64: 355 -365 .

271. Furtuno A, Rodriguez A, Gomez-Ambrosi J, Fruhbeck G, Dieg $\mathrm{J}$. Adipose tissue as an endocrine organ: role of leptin and adiponectin in the pathogenesis of cardiovascular diseases. J Physiol Biochem 2003; 49: 51-60.

272. Mora S, Pessin JE. An adipocentric view of signaling and intracellular trafficking. Diabetes Metab Res Rev 2002; 18:345-356.

273. Lyon CJ, Law RE, Hsueh WA. Minireview: adiposity, inflammation, and atherogenesis. Endocrinology 2003; 144:2195-2200.

274. Matsubara M, Maruoka S, Katayose S. Inverse relationship between plasma adiponectin and leptin concentrations in normal-weight and obese women. Eur J Endocrinol 2002; 147: $173-180$.

275. Retnakaran R, Hanley AJ, Raif N, Connelly PW, Sermer M, Zinman B. C-reactive protein and gestational diabetes: the central role of maternal obesity. J Clin Endocrinol Metab 2003; 88: 3507-3512
276. Laimer M, Ebenbichler CF, Kaser S, Sandhofer A, Weiss H, Nehoda $\mathrm{H}$. Markers of chronic inflammation and obesity: a prospective study on the reversibility of this association in middle-aged women undergoing weight loss by surgical intervention. Int J Obes Relat Metab Disord 2002; 26 : $659-662$.

277. Yudkin JS, Stehouwer CD, Emeis JJ, Coppack SW. C-reactive protein in healthy subjects: associations with obesity, insulin resistance, and endothelial dysfunction: a potential role for cytokines originating from adipose tissue? Arterioscler Thromb Vasc Biol 1999; 19: 972-978.

278. Engeli S, Peldpausch M, Gorzelniak K, Hartwig F, Heintze $\mathrm{U}$, Janke $\mathrm{J}$, et al.Association between adiponectin and mediators of inflammation in obese women. Diabetes 2003; 52: 942-947.

279. Esposito K, Pontillo A, Di Palo C, Giugliano G, Masella M, Marfella R, et al. Effect of weight loss and lifestyle changes on vascular inflammatory markers in obese women: a randomized trial. JAMA 2003; 289: 1799-1804.

280. Ramsay JE, Ferrell WR, Crawford L, Wallace AM, Greer IA, Sattar N. Maternal obesity is associated with dysregulation of metabolic, vascular, and inflammatory pathways. J Clin Endocrinol Metab 2002; 87: 4231-4237.

281. Esposito K, Pontillo A, Giugliano F, Giugliano G, Marfella R, Nicoletti G, et al. Association of low interleukin-10 levels with the metabolic syndrome in obese women. $\mathrm{J}$ Clin Endocrinol Metab 2003; 88: 1055-1058.

282. Vozarova B, Weyer C, Hanson K, Tataranni PA, Bogardus C Pratley RE. Circulating interleukin-6 in relation to adiposity, insulin action, and insulin secretion. Obes Res 2001; 9 414-417

283. Skurk T, Van Harmelen V, Lee YM, Wirth A, Hauner $H$. Relationship between IL-6, leptin and adiponectin and variables of fibrinolysis in overweight and obese hypertensive patients. Horm Metab Res 2002; 34: 659663.

284. Bruun JM, Verdich C, Toubro S, Astrup A, Richelsen B. Association between measures of insulin sensitivity and circulating levels of interleudin-8, interleukin-6 and tumor necrosis factor- $\alpha$. Effect of weight loss in obese men. Eur J Endocrinol 2003; 148: 535-542.

285. Bastard JP, Maachi M, Van Nhieu JT, Jardel C, Bruckert E, Grimaldi A, et al. Adipose tissue IL-6 content correlates with resistance to insulin activation of glucose uptake both in vivo and in vitro. J Clin Endocrinol Metab 2002; 87:2084-2089.

286. Straczkowski M, Dzienis-Straczkowska S, Stepien A, Kowalska I, Szelachowska M, Kinalska I . Plasma interleukin-8 concentrations are increased in obese subjects and related to fat mass and tumor necrosis factor- $a$ system. J Clin Endocrinol Metab 2002; 87: 4602-4606

287. Primrose JN, Davies JA, Prentice CR, Hughes R, Johnston D. Reduction in factor VII, fibrinogen and plasminogen activator inhibitor-1 activity after surgical treatment of morbid obesity. Thromb Haemost 1992; 68: 396-399.

288. Carmichael AR, Tate G, King RF, Sue-Ling HM, Johnston D. Effects of the Magenstrasse and Mill operation for obesity on plasma plasminogen activator inhibitor type 1, tissue plasminogen activator, fibrinogen and insulin. Pathophysiol Haemost Thromb 2002; 32: 40-43.

289. Sylvan A, Rutegard JN, Janunger KG, Sjolund B, Nilsson TK. Normal plasminogen activator inhibitor levels at long-term follow-up after jejuno-ileal bypass surgery in morbidly obese individuals. Metabolism 1992; 41:1370-1372.

290. Sasaki A, Kurisu A, Ohno M, Ikeda Y. Overweight/obesity, smoking, and heavy alcohol consumption are important determinants of plasma PAI-1 levels in healthy men. Am J Med Sci 2001; 322:19-23. 
291. Katsuki A, Sumida Y, Murashima S, Murata K, Takarada Y, Ito $K$, et al. Serum levels of tumor necrosis factor- $\alpha$ are increased in obese patients with noninsulin-dependent diabetes mellitus. J Clin Endocrinol Metab 1998; 83: 859862.

292. Rehman J, Considine RV, Bovenkerk JE, Li J, Slavens CA, Jones RM, et al. Obesity if associated with increased levels of circulating hepatocyte growth factor. J Am Coll Cardiol 2003; 41:1 408-1413.

293. Skurk T, Alberti - Huber C, Herder C, Hauner H. Relationship between adipocyte size and adipokine expression and secretion. J Clin Endocrinol Metab 2007; 92: 1023 1033.

294. Björntorp P. The regulation of adipose tissue distribution in humans. Int J Obes 1996; 20: 291 - 302.

295. Regazzetti C, Peraldi P, Grémeaux T, Najem-Lendom R, BenShara I, Cormont M. Hypoxia decreases insulin signaling pathways in adipocytes. Diabetes 2009; 58: 95 - 103.

296. Gustafson B, Hammarstedt A, Andersson CX, Smith U. Inflamed adipose tissue: a culprit underlying the metabolic syndrome and atherosclerosis. Arterioscler Thromb Vasc Biol 2007; 27: 2276-2283.

297. Guilherme A, Virbasius JV, Puri V, Czech MP. Adipocyte dysfunctions linking obesity to insulin resistance and type 2 diabetes. Nat Rev Mol Cell Biol 2008; 9: 367-377.

298. Hotamisligil GS. Inflammation and metabolic disorders. Nature 2006; 444: 860-867.

299. Gustafson B, Smith U. Cytokines promote Wnt signaling and inflammation and impair the normal differentiation and lipid accumulation in 3T3-L1 preadipocytes. J Biol Chem 2006; 281: 9507-9516.

300. Rotter V, Nagaev I, Smith U. Interleukin-6 (IL-6) induces insulin resistance in 3T3-L1 adipocytes and is, like IL-8 and tumor necrosis factor-alpha, overexpressed in human fat cells from insulin-resistant subjects. J Biol Chem 2003; 278: 45777-45784.

301. Sevastianova K, Sutinen J, Kannisto K, Hamsten A, Ristola $\mathrm{M}$, Yki-Jarvinen $\mathrm{H}$. Adipose tissue inflammation and liver fat in patients with highly active antiretroviral therapyassociated lipodystrophy. Am J Physiol Endocrinol Metab 2008; 295: E85-E91.

302. Brook CG, Lloyd JK, Wolf OH. Relation between age of onset of obesity and size and number of adipose cells. $\mathrm{Br}$ Med J 1972; 2:25-27

303. Helmlinger G, Yuan F, Dellian M, Jain RK. Interstitial pH and pO2 gradients in solid tumors in vivo: high-resolution measurements reveal a lack of correlation. Nat Med 1997; 3:177-182

304. Semenza GL. Surviving ischemia: adaptive responses mediated by hypoxiainducible factor 1 . J Clin Invest 2000; 106:809-812.

305. Mori K. Tripartite management of unfolded proteins in the endoplasmic reticulum. Cell 2000; 101:451-454.

306. Hotamisligil GS, Shargill NS, Spiegelman BM. Adipose expression of tumor necrosis factor-alpha: direct role in obesity-linked insulin resistance. Science 1993; 259:8791.

307. Kahn BB, Flier JS. Obesity and insulin resistance. J Clin Invest 2000; 106:473-481.

308. Yamaguchi T, Kamon J, Waki H, Terauchi Y, Kubota N, Hara $\mathrm{K}$, et al. The fat-derived hormone adiponectin reverses insulin resistance associated with both lipoatrophy and obesity. Nat Med 2001; 7:941-946.

309. Maeda N, Shimomura I, Kishida K, Nishizawa H, Matsuda M, Nagaretani $\mathrm{H}$, et al. Diet-induced insulin resistance in mice lacking adiponectin/ACRP30. Nat Med 2002; 8:731-737.
310. Trayhurn P. Endocrine and signalling role of adipose tissue: new perspectives on fat. Acta Physiol Scand 2005; 184:285-293.

311. Gregor MF, Hotamisligil GS. Adipocyte stress: the endoplasmic reticulum and metabolic diseases. J Lipid Res 2007; 48: $1905-1914$.

312. Qatanani M, Lazar MA. Mechanisms of obesity - associated insulin resistance: many choices on the menu. Genes Dev 2007; 21: 1443 - 1455.

313. Shoelson SE, Goldfine AB. Fanning the flames of obesity induced inflammation. Nat Med 2009; 15: $373-374$.

314. Yki-Jarvinen $\mathrm{H}$, Westerbacka J. The fatty liver and insulin resistance. Curr Mol Med 2005; 5: 287-95

315. Weisberg S, McCann D, Desai M, Rosenbaum M, Leibel $\mathrm{R}$, Ferrante A. Obesity is associated with macrophage accumulation in adipose tissue. J Clin Invest 2003; 112 : 1796-1808.

316. Greenberg AS, Obin MS. Obesity and the role of adipose tissue in inflammation and metabolism. Am J Clin Nutr 2006; 83 : S461-5.

317. Shoelson SE, Lee J, Goldfine AB. Inflammation and insulin resistance. J Clin Invest 2006; 116: 1793-801.

318. Xu H, Barnes GT, Yang Q, Tan G, Yang D, Chou CJ, et al. Chronic inflammation in fat plays a crucial role in the development of obesity-related insulin resistance. J Clin Invest 2003; 112: 1821-30.

319. Eckel RH, Grundy SM, Zimmet PZ. The metabolic syndrome. Lancet 2005; 365: 1415-28.

320. Murano I, Barbatelli G, Parisani V, Latini C, Muzzonigro G, Castellucci M, et al. Dead adipocytes, detected as crownlike structures (CLS), are prevalent in visceral fat depots of genetically obese mice. J Lipid Res 2008; 49: 1562-8.

321. Lang $\mathrm{R}$, Bishop J: Macrophages are required for cell death and tissue remodeling in the developing mouse eye. Cell 1993; 74: 453- 462.

322. Sorimachi K, Akimoto K, Tsuru K, leiri T, Niwa A: The involvement of tumor necrosis factor in the multinucleation of macrophages. Cell Biol Int 1995; 19: 547-549.

323. Strissel KJ, Stancheva Z, Miyoshi H, Perfield JW, DeFuria HJ, Jick Z, et al. Adipcyte death, adipose tissue remodeling, and obesity complications. Diabetes 2007; 56: $2910-$ 2918.

324. Boden G. Endoplasmic reticulum stress: another link between obesity and insulin resistance/inflammation? Diabetes 2009; 58: $518-519$.

325. Lai E, Bikopoulos G, Wheeler MB, Rozakis-Adcock M, Volchuk A. Differential activation of ER stress and apoptosis in response to chronically elevated free fatty acids in pancreatic $\beta$-cells. Am J Physiol Endocrinol Metab 2008; 294:E540-E550.

326. Zhang K, Kaufman RJ. From endoplasmic-reticulum stress to the inflammatory response. Nature 2008; 45:455- 462.

327. Hirosumi J, Tuncman G, Chang L, Gorgun CZ, Uysal KT, Maeda $\mathrm{K}$, et al. A central role for JNK in obesity and insulin resistance. Nature 2002; 420:333-336.

328. Schroder M, Kaufman RJ. The mammalian unfolded protein response. Annu Rev Biochem 2005; 74:739 -789.

329. Berg AH, Lin Y, Lisanti MP, Scherer PE. Adipocyte differentiation induces dynamic changes in ND-KB

330. Yuan M, Konstantopoulos N, Lee J, Hansen L, Li ZW, Karin $M$, et al. Reversal of obesity- and diet-induced insulin resistance with salicylates or targeted disruption of Ikkbeta. Science 2001; 293: 1673-1677.

331. Zoico E, Zamboni M, Bosello O. New insight into obesity and inflammation. Obes Metab 2009; $5: 1-3$. 
332. Charriére G, Cousin B, Arnaud E, André M, Bacou F, Pénicaud $\mathrm{L}$, et al. Preadipocyte conversion to macrophage. J Biol Chem 203; 278: 9850 - 9855.

333. Cowan CM, Shi YY, Aalami OO, Chou YF, Mari C, Thomas R, et al. Adipose - derived adult stromal cells heal critical - size mouse calvarial defects. Nat Biotechnol 2004; 22: $560-567$.

334. Erickson GR, Gimble JM, Franklin DM, Rice HE, Awad $\mathrm{H}$, Guilak F. Chondrogenic potential of adipose tissue derived stromal cells in vitro and in vivo. Biochem Biophys Res Commun 2002; 290: 763 - 769.

335. Rodriguez AM, Pisani D, Dechesne CA, Turc-Carel C, Kurzenne JY, Wdziekonski B, et al. Transplantation of a multipotent cell population from human adipose tissue induces dystrophin expression in the immunocompetent mdx mouse. J Exp Med 2005; 201: 1397 - 1405

336. Miyahara $Y$, Nagaya $N$, Kataoka $M$, Yanagawa B, Tanaka $K$, $\mathrm{Hao} \mathrm{H}$, et al. Monolayered mesenchymal stem cells repair scarred myocardium after myocardial infarction. Nat Med 2006; $12: 459-465$.

337. Safford KM, Hicok KC, Safford SD, Halvorsen YD, Wilkison WO, Gimble JM, et al. Neurogenic differentiation of murine and human adipose - derived stromal cells. Biochem Biophys Res Commun 2002; 294: 371 - 379.

338. Gimble JM, Katz AJ, Bunnel BA. Adipose - derived stem cells for regenerative medicine. Circ Res 2007; 100: 1249 1260.

339. Lendeckel S, Jödicke A, Christophis $P$, Heidinger $K$, Wolff $J$, Fraser JK, et al. Autologous stem cells (adipose) and fibrin glue used to treat widespread traumatic calvarial defects: case report. J Craniomaxillofac Surg 2004; 32: 370 373.
340. Garcia - Olmo D, Garcia Arranz M, Herreros D, Pascual I, Peiro C, Rodriguez - Montes JA. A phase I clinical trial $f$ the treatment of Crohn's fistula by adipose mesenchymal stem cell transplantation. Dis Colon Rectum 2005; 48 : $1416-1423$.

341. Fang B, Song Y, Lin Q, Zhang Y, Cao Y, Zhao RC, et al. Human adipose tissue - derived mesenchymal stromal cells as salvage therapy for treatment of severe refractory acute graft - vs - host disease in two children. Pediatr Transplant 2007; $11: 814-817$.

342. Yoshimura K, Sato K, Aoi N, Kurita M, Hirohi T, Harii K. Cell - assisted lipotransfer (CAL) for cosmetic breast augmentation - supportive use of adipose - derived stem/ stromal cells. Aesthetic Plast Surg 2008; 32: 48 - 55.

343. Yoshimura K, Sato K, Aoi N, Kurita M, Inoue K, Suga H, et al. Cell assisted lipotransfer for facial lipoatrophy: efficacy of clinical of adipose - derived stem cells. Dermatol Surg 2008; 34: $1178-1185$.

344. Yoshimura K, Asano $Y$, Aoi N, Kurita M, Oshima Y, Sato K, et al. Progenitor - enriched adipose tissue transplantation as rescue for breast implant complications. Breast J 2008;

345. Yoshimura K, Asano Y. Fat injection to the breast: cosmetic augmentation, implant replacement, inborn deformity, and reconstruction after mastectomy. In: Aesthetic and Reconstructive Surgery of the Breast. Hall - Findlay EJ, Evans GRD (Eds). Elsevier Ltd, London, UK. 2008.

346. Yoshimura K, Suga H, Eto H. Adipose-derived stem/progenitor cells: roles in adipose tissue remodeling and potential use for soft tissue augmentation. Regen Med 2009; 4: 265 273. 